\title{
Impact of North America on the aerosol composition in the North Atlantic free troposphere
}

\author{
M. Isabel García ${ }^{1,2}$, Sergio Rodríguez ${ }^{1}$, and Andrés Alastuey ${ }^{3}$ \\ ${ }^{1}$ Izaña Atmospheric Research Centre, AEMET, Joint Research Unit of CSIC "Studies on Atmospheric Pollution", \\ Santa Cruz de Tenerife, 38001, Spain \\ ${ }^{2}$ Department of Chemistry (T.U. Analytical Chemistry), Faculty of Science, University of La Laguna, \\ La Laguna, 38206, Spain \\ ${ }^{3}$ Institute of Environmental Assessment and Water Research, CSIC, Barcelona, 08034, Spain \\ Correspondence to: Sergio Rodríguez (srodriguezg@aemet.es)
}

Received: 24 January 2017 - Discussion started: 27 February 2017

Revised: 11 May 2017 - Accepted: 22 May 2017 - Published: 20 June 2017

\begin{abstract}
In the AEROATLAN project we study the composition of aerosols collected over $\sim 5$ years at Izaña Observatory (located at $\sim 2400 \mathrm{~m}$ a.s.l. in Tenerife, the Canary Islands) under the prevailing westerly airflows typical of the North Atlantic free troposphere at subtropical latitudes and midlatitudes. Mass concentrations of sub- $10 \mu \mathrm{m}$ aerosols $\left(\mathrm{PM}_{10}\right)$ carried by westerly winds to Izaña, after transatlantic transport, are typically within the range 1.2 and $4.2 \mu \mathrm{g} \mathrm{m}^{-3}$ (20th and 80th percentiles). The main contributors to background levels of aerosols $\left(\mathrm{PM}_{10}\right.$ within the 1st-50th percentiles $=0.15-2.54 \mu \mathrm{g} \mathrm{m}^{-3}$ ) are North American dust (53\%), non-sea-salt sulfate $(14 \%)$ and organic matter $(18 \%)$. High $\mathrm{PM}_{10}$ events (75th-95th percentiles $\approx 4.0$ $\left.9.0 \mu \mathrm{g} \mathrm{m}^{-3}\right)$ are prompted by dust $(56 \%)$, organic matter $(24 \%)$ and non-sea-salt sulfate (9\%). These aerosol components experience a seasonal evolution explained by (i) their spatial distribution in North America and (ii) the seasonal shift of the North American outflow, which migrates from low latitudes in winter $\left(\sim 32^{\circ} \mathrm{N}\right.$, January-March) to high latitudes in summer $\left(\sim 52^{\circ} \mathrm{N}\right.$, August-September). The westerlies carry maximum loads of non-sea-salt sulfate, ammonium and organic matter in spring (March-May), of North American dust from midwinter to mid-spring (February-May) and of elemental carbon in summer (August-September). Our results suggest that a significant fraction of organic aerosols may be linked to sources other than combustion (e.g. biogenic); further studies are necessary for this topic. The present study suggests that long-term evolution of the aerosol composition in the North Atlantic free troposphere
\end{abstract}

will be influenced by air quality policies and the use of soils (potential dust emitter) in North America.

\section{Introduction}

The export of aerosols from their source areas impacts on air quality (Chin et al., 2007) and climate-related processes (Ramanathan et al., 2001) in downwind receptor regions. Exposure to aerosols or particulate matter (PM) and reactive gases in ambient air pollution are associated with $\sim 3.7$ million deaths a year, mostly due to ischaemic heart disease $(\sim 40 \%)$, stroke $(\sim 40 \%)$, chronic obstructive pulmonary disease $(\sim 11 \%)$, lung cancer $(\sim 6 \%)$ and acute lower respiratory infections in children $(\sim 3 \%)$ according to the World Health Organization (WHO, 2014). Aerosols are of special interest as they may have an influence on direct radiative transfer and cloud properties by altering the radiative effect and rain patterns. It is estimated that globally, this influence results in mean radiative forcing due to aerosol radiation and aerosol-cloud interaction of about $-0.9 \mathrm{~W} \mathrm{~m}^{-2}$. The aerosol radiation contribution $\left(-0.35 \mathrm{~W} \mathrm{~m}^{-2}\right)$ is the result of the net contribution of sulfate $(-0.4)$, black carbon $(+0.4)$, nitrate $(-0.11)$, dust $(-0.1)$ and organics $(-0.12)$, according to the Intergovernmental Panel on Climate Change (IPCC, 2013; Myhre et al., 2013).

North America is a major source of aerosols and trace gases (Li et al., 2004; Park et al., 2003, 2004). The export of trace gases to the North Atlantic in the so-called North 
American outflow (Li et al., 2005) is enhanced by midlatitude cyclones (Dickerson et al., 1995; Merrill and Moody, 1996; Moody et al., 1996). These cyclones frequently form on the lee side of the Rocky Mountains and propagate eastward, with associated cold fronts south-eastward across the eastern United States (US; Whittaker and Horn, 1984; Zishka et al., 1980). The cyclones occur every 5 days on average in summer (Li et al., 2005), although in spring that frequency may be even higher. Four airstreams are associated with midlatitude cyclones: the warm conveyor belt ahead of the cold front, the cold conveyor belt, the dry airstream subsiding behind the cold front, and the post-cold-front boundary layer airstream (Cooper et al., 2002a, b). The northeastward ascending airstream represented by the warm conveyor belt prompts the upward transport of pollutants from North America to the free troposphere over the North Atlantic (Eckhardt et al., 2004), where it may connect with the westerly circulation at the north of the Azores High (Li et al., 2005) prompting the transatlantic transport of pollutants; this has been documented for relatively long lifetime (LT) trace gases, such as $\mathrm{CO}$ (LT $\sim 60$ days) and $\mathrm{O}_{3}$ (LT $\sim 25$ days) (Honrath et al., 2004; Owen et al., 2006). Convection is also an important mechanism for ventilation of the boundary layer: the convective outflow prompts the upward transport of pollutants (Dickerson et al., 1987; Talbot et al., 1998), which may remain over North America for several days prompting ozone production and its subsequent export to the North Atlantic ( $\mathrm{Li}$ et al., 2005). This mechanism is important in the south-eastern United States in summer, as the warm conveyor belt of the midlatitude cyclones is shifted northward (Li et al., 2005). There is significant observation-based evidence on the large-scale impact of the $\mathrm{CO}$ and $\mathrm{O}_{3}$ pollution events in the North Atlantic linked to North American fires and pollution export (Parrish et al., 1998; Moody et al., 1996; Honrath et al., 2004; Owen et al., 2006).

Although aerosols have been less studied, some research has found evidence of their export to the Atlantic in the cyclone-modulated North American outflow (Li et al., 2005), even if they have a relatively short lifetime (LT $\sim 15$ days). Using ground-based and airborne lidar measurements, Ancellet et al. (2016) detected the transatlantic transport of North American biomass burning aerosols and dust to the Mediterranean. At Pico Observatory in the Azores, free troposphere transport of North American black carbon aerosols linked to boreal fires (Val Martín et al., 2006) and sulfate, nitrate, elemental carbon and organic aerosols (such as biomass burning) has been detected (Dzepina et al., 2015). Modelling studies have also shown evidence of intercontinental transport of aerosols (Park et al., 2004; Chin et al., 2007).

Previous studies on transatlantic transport of North American aerosols have reported on events detected in intensive campaigns, typically lasting from weeks to a few months. In this study we have used a complementary approach based on long-term records. We analysed the long-term aerosol chemistry register of the Izaña Observatory, located at $\sim 2400 \mathrm{~m}$ a.s.l. on the island of Tenerife, with the aim of identifying the composition, potential sources and origin of the aerosols transported by westerly winds across the North Atlantic. To our knowledge, this is the first study addressing the issue.

\section{Methods}

\subsection{Sampling site}

The Izaña Global Atmospheric Watch (GAW) observatory is located on a mountain ridge ( $\sim 2400 \mathrm{~m}$ a.s.l.) lying almost permanently above the temperature inversion and marine stratocumulus layer typical of the marine boundary layer (MBL) top in the subtropics. Buoyant upslope winds develop during daylight with minimum impact on the aerosol mass concentrations (Rodríguez et al., 2009). At night, upslope winds cease and Izaña is exposed to the prevailing westerly free-troposphere-subsiding airflow.

\subsubsection{Sampling and chemical composition}

This study is based on a long-term record of chemical composition of PM smaller than $10 \mu \mathrm{m}\left(\mathrm{PM}_{10}\right)$ and $2.5 \mu \mathrm{m}$ $\left(\mathrm{PM}_{2.5}\right)$ aerodynamic diameters at Izaña Observatory. A total of $401 \mathrm{PM}_{10}$ and $315 \mathrm{PM}_{2.5}$ samples were collected and chemically analysed from February 2008 to August 2013.

The samples of $\mathrm{PM}_{10}$ were collected on quartz microfibre filters $\left(150 \mathrm{~mm}\right.$ diameter) pre-heated at $205^{\circ} \mathrm{C}$ for $5 \mathrm{~h}$; this procedure removes potentially adsorbed volatile carbon. Aerosol sampling was performed at $30 \mathrm{~m}^{3} \mathrm{~h}^{-1}$ flow rate overnight (22:00 to 06:00 GMT), under the influence of free troposphere airflows. One $\mathrm{PM}_{x}$ sample was collected every 3 days, except in August, when sampling was daily. Concentrations of $\mathrm{PM}_{x}$ were determined by gravimetry following the European standard gravimetric measurement method EN14907 (except that filter conditioning was performed at 30$35 \%$ relative humidity instead of $50 \%$ ). The manual gravimetric method is considered optimal for $\mathrm{PM}_{x}$ concentrations $>10 \mu \mathrm{g} \mathrm{m}^{-3}$ (EN-14907), so uncertainties are higher below this threshold value (details in Sect. S1 of the Supplement). Blank weighing room and blank field filters were collected and weighed as part of the quality assurance / quality control (QA / QC) protocol.

The methods used in the long-term ( 30-years) aerosol chemical composition record of Izaña Observatory are described in detail in previous articles (Rodríguez et al., 2015). Briefly, in the study period (2008-2013) soluble species were determined by ion chromatography $\left(\mathrm{SO}_{4}^{=}, \mathrm{NO}_{3}^{-}, \mathrm{Cl}^{-}\right.$; detection limits of $0.113,0.113$ and $0.505 \mu \mathrm{g} \mathrm{m}^{-3}$ respectively) and selective electrode $\left(\mathrm{NH}_{4}^{+}\right.$; detection limit is $0.056 \mathrm{\mu g} \mathrm{m}^{-3}$ ). Elemental composition was determined by Inductively Coupled Plasma Atomic Emission Spectrometry (ICP-AES, IRIS Advantage TJA Solutions, THERMO ${ }^{\mathrm{TM}}$ ) and 
Inductively Coupled Plasma Mass Spectrometry (ICP-MS, $\mathrm{X}$ Series II, THERMO ${ }^{\mathrm{TM}}$ ) after acid digestion of the samples. Organic and elemental carbon (detection limits of 0.8 and $0.032 \mu \mathrm{g} \mathrm{m}^{-3}$ respectively) were analysed by thermaloptical transmittance (TOT, Sunset Laboratory Inc. ${ }^{\mathrm{TM}}$ ) following the EUSAAR2 protocol (Cavalli et al., 2010). Because quartz microfiber filters may adsorb volatile carbon very easily due to the high active surface (Chai et al., 2012), the more unstable part of the organic carbon was discarded based on the results of the field blank filter analysis. Sulfate was split into sea salt sulfate (ss- $\mathrm{SO}_{4}^{=}$) and non-sea-salt sulfate (nss- $\mathrm{SO}_{4}^{=}$) using the empirical ratio of $\mathrm{Na}$ and sulfate $\left(\mathrm{SO}_{4}^{=} / \mathrm{Na}^{+}=0.25\right)$ in seawater (Gravenhorst, 1978), which assumes there is no sulfate enrichment due to gas-to-particle conversion of the oxidation of marine $\mathrm{SO}_{2}$ (Bonsang et al., 1980). Organic matter (OM) was determined by using the ratio $\mathrm{OM} / \mathrm{OC}=1.8$ observed in the North American aerosols collected at Pico Observatory in the Azores (Dzepina et al., 2015). Blank field filters were subject to gravimetry and chemical analysis, and mean values were subtracted from the $\mathrm{PM}_{x}$ samples.

The chemical composition data were used for a mass closure of $\mathrm{PM}_{x}$ (Table 1). The undetermined fraction of PM, i.e. the difference between the gravimetrically determined $\mathrm{PM}_{x}$ and the sum of the chemical compounds, increased under low $\mathrm{PM}_{x}$ conditions. This has already been observed in previous studies (Ripoll et al., 2015) and is attributed to inaccuracies of the manual gravimetric method under low PM concentrations $\left(<10 \mu \mathrm{g} \mathrm{m}^{-3}\right)$ and to the relatively higher contribution of water not fully removed during filter conditioning.

\subsection{Meteorology, back-trajectories and MCAR plots}

We analysed meteorological reanalysis data from the $\mathrm{Na}$ tional Centre for Environmental Prediction/National Centre for Atmospheric Research (NCEP/NCAR) (Kalnay et al., 1996) to study the processes involved in the export and transatlantic transport of aerosols from North America. The analysis includes geopotential heights, winds and omega (vertical wind) at several standard levels $(925,850$ and $700 \mathrm{hPa}$ ) and precipitation rates.

Three-dimensional 10-day back-trajectories were computed at 00:00 GMT for Izaña using the meteorological input data from the European Centre for Medium-Range Weather Forecasts (ECMWF) and Lagrangian model FLEXTRA (Stohl et al., 1995; Stohl and Seibert, 1998). These back-trajectories were used as input in a self-developed Matlab script (The Mathworks, Natick, USA) which segregates air masses coming from North America and the North Atlantic from those from Africa, attending to the latitude and longitude values along the transport path towards Izaña (details in Sect. S2). The frequency of the westerlies and of the Saharan Air Layer at Izaña is shown in Fig. 1C. Samples of $\mathrm{PM}_{10}$ and $\mathrm{PM}_{2.5}$ were associated with westerlies and
SAL according to the back-trajectories (Fig. S2 in the Supplement).

We determined the Median Concentrations At Receptor (MCAR) plots for the main $\mathrm{PM}_{10}$ chemical component using the method described by Rodríguez et al. (2011). In these MCAR, the typical (median) concentration of each aerosol component recorded at Izaña, when the air mass has passed by each pixel of the study region, is plotted. The MCAR plots were calculated with back-trajectories that are representative of transatlantic transport from North America. Events linked to (i) back-trajectories from northern Africa or (ii) associated with Saharan dust that recirculated over the North Atlantic (exported from northern Africa westward and then recirculated eastward, e.g. as described by Ancellet et al. (2016)) were removed. To identify the latter type of events we also used the output forecasts of the BSC-DREAM8b model (Pérez et al., 2006; Basart et al., 2012) storages at the Barcelona Supercomputing Centre website (http://www.bsc. es/ESS/bsc-dust-daily-forecast). Similar plots were used to analyse the seasonality of the frequency of westerlies reaching Izaña, which is linked to the export of North American pollutants. Monthly transport route frequency (TRF) plots for the period 2008-2013 were calculated in a similar way to the MCAR plots, but instead of the median concentration, the total number of back-trajectories passing by each cell grid is represented.

\subsection{Complementary data}

We used the Global Fire Emissions Database Version 4 including small fires data (GFEDv4.1s; Randerson et al., 2015) to estimate the average burned fraction of each $0.25^{\circ} \times 0.25^{\circ}$ grid cell in North America during the study period (20082013). The data set was downloaded from the Oak Ridge National Laboratory Distributed Active Archive Center (ORNL DAAC) for biogeochemical dynamics (https://daac.ornl.gov/ cgi-bin/dsviewer.pl?ds_id=1293). We also made use of Level 3 UV Aerosol Index (AI) data, from the Ozone Monitor Instrument spectrometer on board satellite Aura (OMI 20082013), to study the spatial and temporal variability of dust in North America during the study period (2008-2013). The data set was downloaded from the Giovanni online data system of the NASA Goddard Earth Sciences Data and Information Services Center (GES DISC; http://disc.sci.gsfc.nasa. gov/).

\section{Results and discussion}

\subsection{Chemical characterisation}

This study focuses on aerosols transported by the westerlies, i.e. the westerly airstream that flows from North America across the North Atlantic at subtropical latitude and midlatitudes. Previous studies have shown that the Saharan Air Layer (SAL), i.e. the dusty airstream that expands from 
Table 1. Mass closure and median concentrations of $\mathrm{PM}_{10}$ and $\mathrm{PM}_{2.5}$ components in samples collected when Izaña was (i) within the Saharan Air Layer (SAL) and (ii) within the westerlies (WES). Only days when $\mathrm{PM}_{10}$ and $\mathrm{PM}_{2.5}$ were sampled simultaneously were taken into account. The percentage of the corresponding parameter with respect to the PM is shown.

\begin{tabular}{|c|c|c|c|c|c|c|c|c|}
\hline \multirow[b]{2}{*}{ NS } & \multicolumn{4}{|c|}{ Saharan Air Layer } & \multicolumn{4}{|c|}{ Westerlies } \\
\hline & $\begin{array}{r}\mathrm{PM}_{10} \\
146\end{array}$ & $\%$ & $\begin{array}{r}\mathrm{PM}_{2.5} \\
146\end{array}$ & $\%$ & $\begin{array}{r}\mathrm{PM}_{10} \\
96\end{array}$ & $\%$ & $\begin{array}{r}\mathrm{PM}_{2.5} \\
96\end{array}$ & $\%$ \\
\hline \multicolumn{9}{|l|}{ Mass closure } \\
\hline $\mathrm{PM}, \mu \mathrm{g} \mathrm{m}^{-3}$ & 46.42 & & 21.27 & & 2.54 & & 2.19 & \\
\hline$\sum, \mu \mathrm{g} \mathrm{m}^{-3}$ & 40.87 & 88 & 15.59 & 73 & 1.78 & 70 & 1.05 & 48 \\
\hline undetermined, $\mu \mathrm{g} \mathrm{m}^{-3}$ & 5.55 & 12 & 5.68 & 27 & 0.75 & 30 & 1.14 & 52 \\
\hline \multicolumn{9}{|l|}{ Median concentrations } \\
\hline dust, $\mu \mathrm{g} \mathrm{m}^{-3}$ & 36.07 & 77.7 & 13.18 & 62.0 & 1.13 & 44.5 & 0.50 & 22.8 \\
\hline sea salt, $\mu \mathrm{g} \mathrm{m}^{-3}$ & $<0.01$ & $\sim 0$ & $<0.01$ & $\sim 0$ & 0.01 & 0.5 & 0.01 & 0.5 \\
\hline $\mathrm{EC}, \mu \mathrm{g} \mathrm{m}^{-3}$ & $<0.01$ & $\sim 0$ & $<0.01$ & $\sim 0$ & 0.02 & 0.6 & 0.01 & 0.3 \\
\hline $\mathrm{OM}, \mu \mathrm{g} \mathrm{m}^{-3}$ & 2.07 & 4.5 & 1.00 & 4.7 & 0.32 & 12.4 & 0.26 & 11.7 \\
\hline $\mathrm{NH}_{4}^{+}, \mu \mathrm{g} \mathrm{m}^{-3}$ & 0.18 & 0.4 & 0.17 & 0.8 & 0.06 & 2.2 & 0.06 & 2.7 \\
\hline $\mathrm{NO}_{3}^{-}, \mu \mathrm{g} \mathrm{m}^{-3}$ & 0.82 & 1.8 & 0.17 & 0.8 & $<0.01$ & $\sim 0$ & $<0.01$ & $\sim 0$ \\
\hline $\mathrm{SO}_{4}^{=}, \mu \mathrm{g} \mathrm{m}^{-3}$ & 1.73 & 3.8 & 1.06 & 5.0 & 0.25 & 10.0 & 0.22 & 10.0 \\
\hline \multicolumn{9}{|l|}{ Sulfate speciation } \\
\hline $\mathrm{ss}^{\mathrm{S}} \mathrm{SO}_{4}^{=}, \mu \mathrm{g} \mathrm{m}^{-3}$ & $<0.01$ & $\sim 0$ & $<0.01$ & $\sim 0$ & $<0.01$ & $\sim 0$ & $<0.01$ & 0.1 \\
\hline nss-SO $=\mathrm{Sg} \mathrm{m}_{4}^{-3}$ & 1.72 & 3.7 & 1.05 & 4.9 & 0.25 & 9.8 & 0.22 & 10.0 \\
\hline $\mathrm{a}-\mathrm{SO}_{4}=\mu \mathrm{g} \mathrm{m}^{-3}$ & 0.48 & 1.0 & 0.45 & 2.2 & nd & nd & nd & nd \\
\hline na-SO $=\overline{4}, \mu \mathrm{g} \mathrm{m}^{-3}$ & 1.22 & 2.6 & 0.55 & 2.6 & nd & nd & nd & nd \\
\hline
\end{tabular}

NS is the number of samples. PM is particulate matter obtained with the gravimetric method. $\sum$ is the summation of the major chemical species (dust + sea salt $+\mathrm{EC}+\mathrm{OM}+\mathrm{NH}_{4}^{+}+\mathrm{NO}_{3}^{-}+\mathrm{SO}_{4}^{=}$). nd is not determined.

northern Africa to the Americas, is the most important carrier of aerosols in the tropical and subtropical North Atlantic (Prospero et al., 1972). Therefore, we first did a brief comparison of the characteristics of the aerosol composition in these two airstreams, with the aim of illustrating the huge differences between them. The frequency of the westerlies and of the SAL at Izaña is shown in Fig. 1c: the westerlies occur with high frequency throughout the year, with a maximum in April-May and a minimum in July-August when Izaña is mostly within the SAL.

Table 1 shows the median chemical composition and mass closure of the $\mathrm{PM}_{10}$ and $\mathrm{PM}_{2.5}$ aerosols in samples collected at Izaña under the SAL and the westerlies (Fig. 1a-b). The transport of particulate pollutants in the SAL had already been studied by Rodríguez et al. (2011). The SAL impacts on Izaña in July and August, and is linked to the northern shift of the Harmattan trade winds (Fig. 1a). The summer SAL occurs $1-5 \mathrm{~km}$ a.s.l. off northern Africa. It is associated with air from the Mediterranean flowing south-westward to the Sahara resulting in the emissions and export of dust to the Atlantic above the marine boundary layer. The westerlies occur throughout the year and are associated with airstreams from North America that, in some cases, may have circulated around the Azores High (Fig. 1a).
Concentrations of bulk $\mathrm{PM}_{10}$ and $\mathrm{PM}_{2.5}$ are $\sim 20$ and 10 times higher in the SAL than in the westerlies respectively (Table 1). Mass closure of $\mathrm{PM}_{x}$ accounts for a rather low fraction of the gravimetrically determined $\mathrm{PM}_{x}$ concentrations under westerly conditions (50-70\% of $\mathrm{PM}_{x}$, Table 1 ), compared to the SAL (70-90\% of $\mathrm{PM}_{x}$, Table 1). This is attributed to the relatively high inaccuracy of the manual gravimetric method under low $\mathrm{PM}_{x}$ concentrations described above (see details in Sect. S1). Thus, the sum of the main chemical components $\left(\sum\right.$ in Table 1$)$ is probably a better proxy of the actual bulk $\mathrm{PM}_{x}$ concentrations in the westerlies than the gravimetric PM concentrations.

In the SAL, the $\mathrm{PM}_{10}$ aerosol population (median of $\sum$ - sum of the main chemical components $-\sim 41 \mu \mathrm{g} \mathrm{m} \mathrm{m}^{-3}$; Table 1$)$ is basically constituted by dust $\left(78 \%: 36 \mu \mathrm{g} \mathrm{m}^{-3}\right)$ mixed with organic matter $\left(4.5 \%: 2.1 \mu \mathrm{g} \mathrm{m}^{-3}\right)$, sulfate (3.8\%: $\left.1.8 \mu \mathrm{g} \mathrm{m}^{-3}\right)$, nitrate $\left(1.8 \%: 0.8 \mu \mathrm{g} \mathrm{m}^{-3}\right)$ and ammonium $\left(0.4 \%\right.$ : $\left.0.2 \mu \mathrm{g} \mathrm{m}^{-3}\right)$. In contrast, $\mathrm{PM}_{10}$ aerosol in the westerlies (median of $\sum$ - sum of the main chemical components $-\sim 1.8 \mu \mathrm{g} \mathrm{m}^{-3}$ ) is predominantly constituted by dust ( $\left.44.5 \%: 1.1 \mu \mathrm{g} \mathrm{m}^{-3}\right)$, organic matter $(12.4 \%$ : $\left.0.32 \mu \mathrm{g} \mathrm{m}^{-3}\right)$, nss-SO= $=\left(9.8 \%: 0.25 \mu \mathrm{g} \mathrm{m}^{-3}\right)$ and ammonium $\left(2.2 \%: 0.06 \mu \mathrm{g} \mathrm{m}^{-3}\right)$. Nitrate in the SAL mostly occurs in the coarse range as non-ammonium salt coating dust parti- 

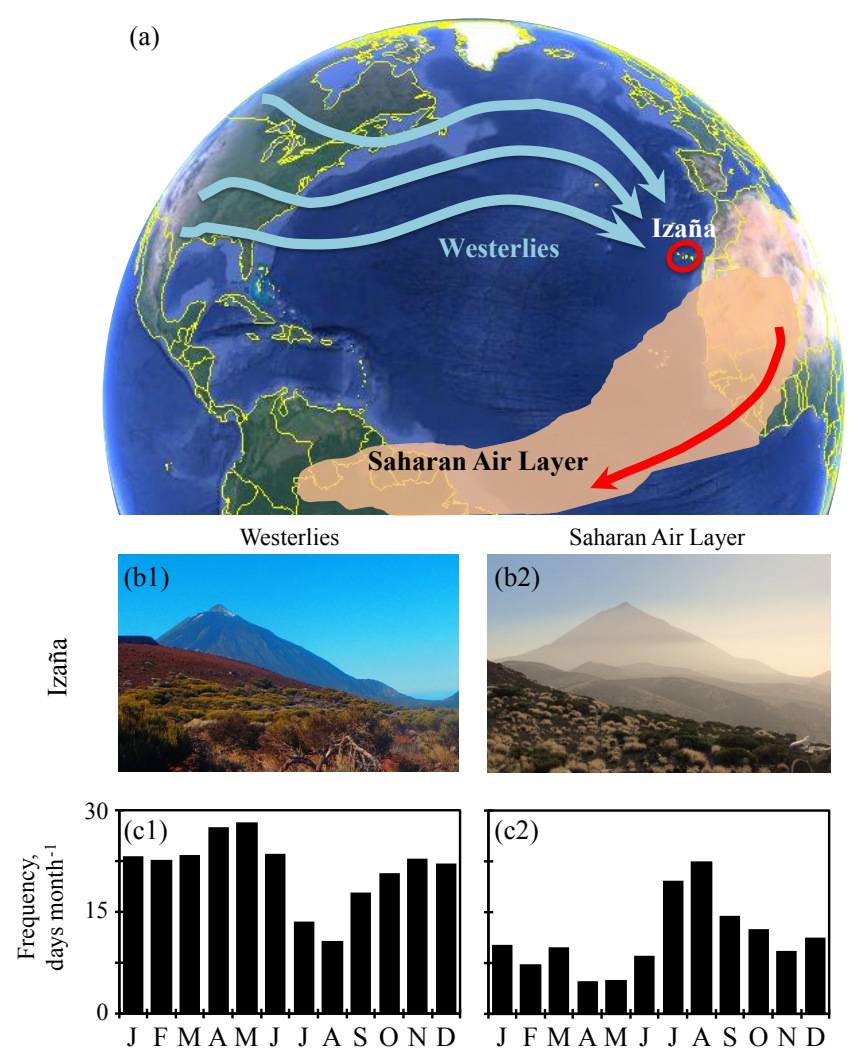

Figure 1. (a) Location of the Izaña Observatory with an illustration of the Saharan Air Layer and the westerlies. (b) View from the Izaña Observatory to the west under the westerly and Saharan Air Layer conditions. (c) Monthly frequency (number of days per month) of westerly and Saharan Air Layer at Izaña based on back-trajectories.

cles (see details in Rodríguez et al., 2011). In the westerlies nitrate concentrations tend to be extremely low. In the few observed nitrate events, it tended to occur in the sub- $2.5 \mu \mathrm{m}$ range, attributed to an ammonium salt. In the SAL, about three-quarters of non-sea-salt sulfate (nss- $\mathrm{SO}_{4}^{=}$) is present as ammonium sulfate (a- $\mathrm{SO}_{4}^{=}$) linked to anthropogenic sulfur emissions, with the remaining three-quarters being nonammonium sulfate (na- $\mathrm{SO}_{4}^{=}$), most probably linked to soil emissions of gypsum/anhydrite soil minerals in beds of Saharan dry lakes (Rodríguez et al., 2011; Pérez García-Pando et al., 2016).

Aerosols in the SAL and in the westerlies also exhibit differences in terms of size distribution. PM mass mostly occurs in the sub-2.5 $\mu \mathrm{m}$ in the westerlies and in the coarse $2.5-10 \mu \mathrm{m}$ range in the SAL (Table 1).

\subsection{North American large-scale meteorology and airstreams}

The meteorological scenarios that prompt pollutant export events from North America are described in previous studies (Merrill and Moody, 1996; Moody et al., 1996; Stohl,
2002; Li et al., 2005; Owen et al., 2006). Here a complementary view is provided. We analysed how large-scale circulations over North America evolve over the year, and more specifically how they may influence the export of aerosols to the Atlantic. The monthly values of key meteorological fields (geopotential heights, winds and omega at several standard levels, 925, 850 and $700 \mathrm{hPa}$ and precipitation rates, e.g. Fig. 2a) were determined with the National Center for Environmental Prediction/National Center for Atmospheric Research (NCEP/NCAR) reanalysis data (Kalnay et al., 1996). To facilitate an interpretation of how the variability in meteorology may influence the export of aerosols we also plotted (i) the latitudinal range of the westerlies over the eastern coast of North America (observed in the monthly NCEP/NCAR wind fields; Fig. 3a), (ii) the spatial distribution of $\mathrm{SO}_{2}$ according to Fioletov et al. (2016) (Fig. 3b) and of major aerosol components according to Park et al. (2003, 2004) (Fig. 4) and (iii) the monthly mean values of the omega vertical component of wind in selected domains (Fig. 3c and 3d). Finally, in order to link the export of North American pollutants with transatlantic transport, the transport route frequency (TRF) field was determined for each month based on back-trajectories (Fig. 2b). Figure 2 shows examples for illustrative months (January, April, August and November); additional material is presented in the Supplement (Fig. S3).

During January and February, the North Atlantic anticyclone shifts southward, expanding over the Caribbean and resulting in an intense geopotential/pressure gradient (Fig. S2a) and westerly winds over most of North America (Fig. 2a1). The main stream of the westerlies (which we refer to as "westerly jet") flows from western Canada $\left(\sim 55^{\circ} \mathrm{N}\right)$ to the eastern US entering the North Atlantic at relatively low latitudes $\left(36-38^{\circ} \mathrm{N}\right.$ in the $850 \mathrm{hPa}$ standard level; Fig. 2a1). We refer to the westerly jet over the eastern coast of North America as the "North American outflow". Its latitudinal position over the year is plotted in Fig. 3a. The TRF analysis shows that during this period air from the central and southern US reaches Izaña (Fig. 2b1).

From March to June, the North Atlantic anticyclone progressively intensifies (Fig. S2b) and the western side of its clockwise atmospheric circulation expands from the inner Gulf of Mexico northward to the central US and then to the eastern US, resulting in an airstream that we have called "the Gulf inflow", which is observed in the wind fields at the 925, 850 and $700 \mathrm{hPa}$ levels (Fig. 2a2). The Gulf inflow is observed from March, when the trade winds building up results in an northward inflow across the coast of Texas, which subsequently turns north-eastward over the central US (Arkansas to Tennessee and Indiana) and then eastward resulting in a westerly outflow to the Atlantic by the eastern coast of North America following the clockwise circulation of the North Atlantic high (Fig. 2b2). The analysis of the (vertical) omega component at the 925,850 and $700 \mathrm{hPa}$ levels shows that upward movement of air occurs in the regions affected by the Gulf inflow of warm and humid air 

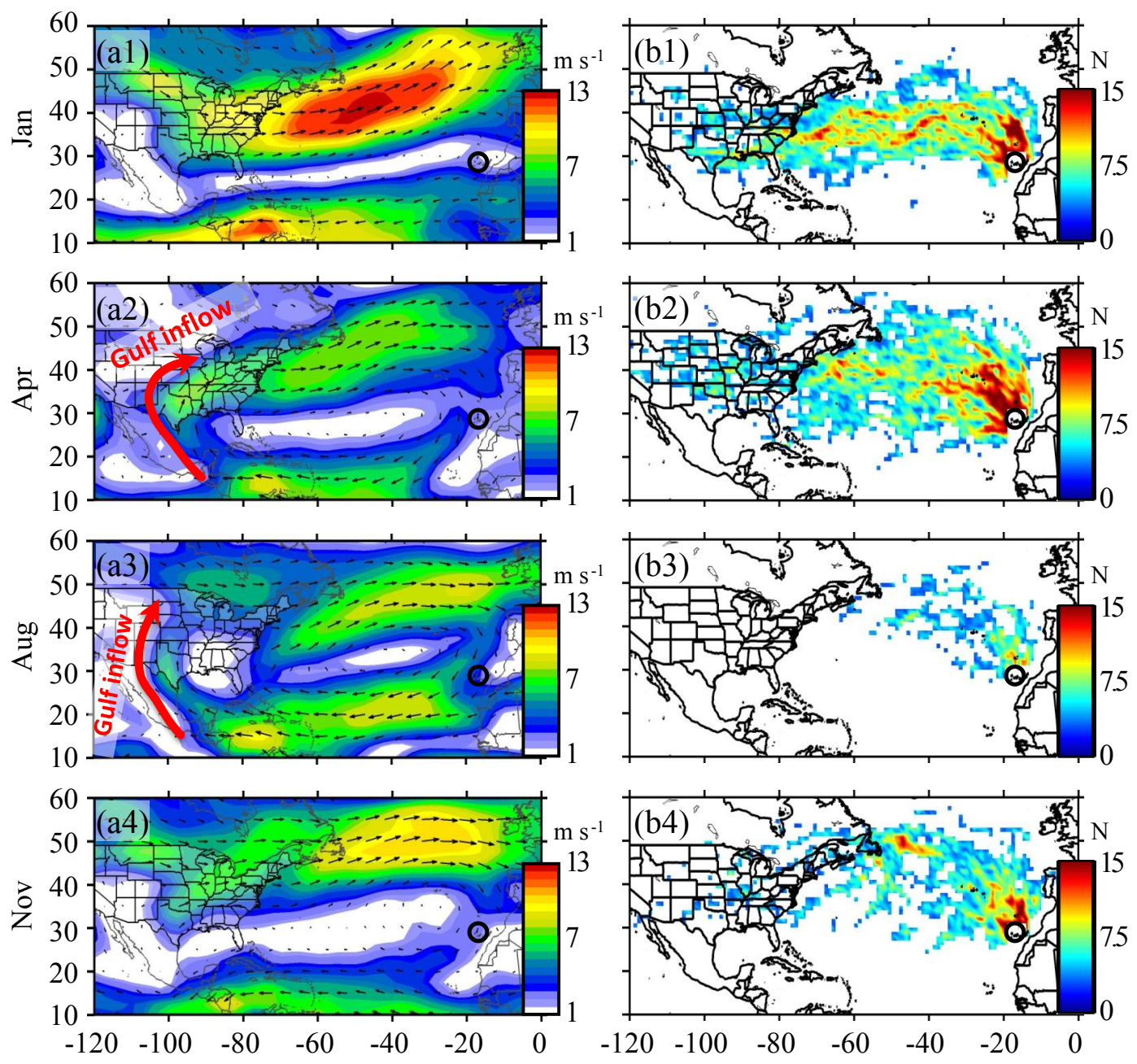

Figure 2. (a) Wind vector at $850 \mathrm{mb}$ and (b) transport route frequency (TRF) for January (Jan), April (Apr), August (Aug) and November (Nov) of the period 2008-2013. The Gulf inflow is highlighted as well as the location of Izaña (black circle).

from Texas to Indiana, in such a way that air masses from the continental boundary layer of the central to north-eastern US may be exported in the westerlies to the North Atlantic free troposphere (Fig. S3b). Observe in Fig. 3c how omega decreases to negative values (net upward movements) from March to May in the central US (domain 1 in Fig. 3d) under the influence of the Gulf inflow. The decrease in omega in this season is also observed to the east (domain 2 in Fig. 3d). This is consistent with the fact that the storm season occurs in this period (March to June) between the central US (northern Texas and Kansas) and the west of the Appalachians (Tennessee, Kentucky and Indiana), as reported by NOAA (http://www.ncdc.noaa.gov/climate-information/ extreme-events/us-tornado-climatology; Sect. S4). Along the path of the Gulf inflow there are a number of sources of aerosols and their precursors, including coal-fired power plants (Fioletov et al., 2016), the emissions of which may be lifted to the mid-troposphere during convective processes (Dickerson et al., 1987; Talbot et al., 1998), and then ex- ported to the North Atlantic free troposphere by the westerly circulation, which in this period tends to occur $35-45^{\circ} \mathrm{N}$ (Fig. 3a). The export of pollutants from the eastern US to the Atlantic is enhanced by eastward-moving cyclones, which have tracks that typically occur south of $40^{\circ} \mathrm{N}$ in this season (Cooper et al., 2002a); Fig. 3b shows an illustration of this scenario (Cooper et al., 2002a, b) and the mean $\mathrm{SO}_{2}$ spatial distribution observed by satellite (Fioletov et al., 2016). A dotted blue line shows the typical eastward track of the cyclones in March-April, whereas the blue arrows indicate a simplified scheme of the associated circulation. The satellite detection of $\mathrm{SO}_{2}$ over the ocean off the coast of Virginia to New Jersey $\left(35-40^{\circ} \mathrm{N}\right.$ in Fig. 3b) shows evidence of the importance of the export of this aerosol sulfate precursor to the Atlantic. The back-trajectory-based TRF analysis shows that air masses from the central US (e.g. domain 1 in Fig. 3d) and the eastern US (e.g. domain 2 in Fig. 3d) are regularly transported to Izaña (Fig. 2b2). Spring (March-April) is the season of maximum frequency of the westerlies at this obser- 

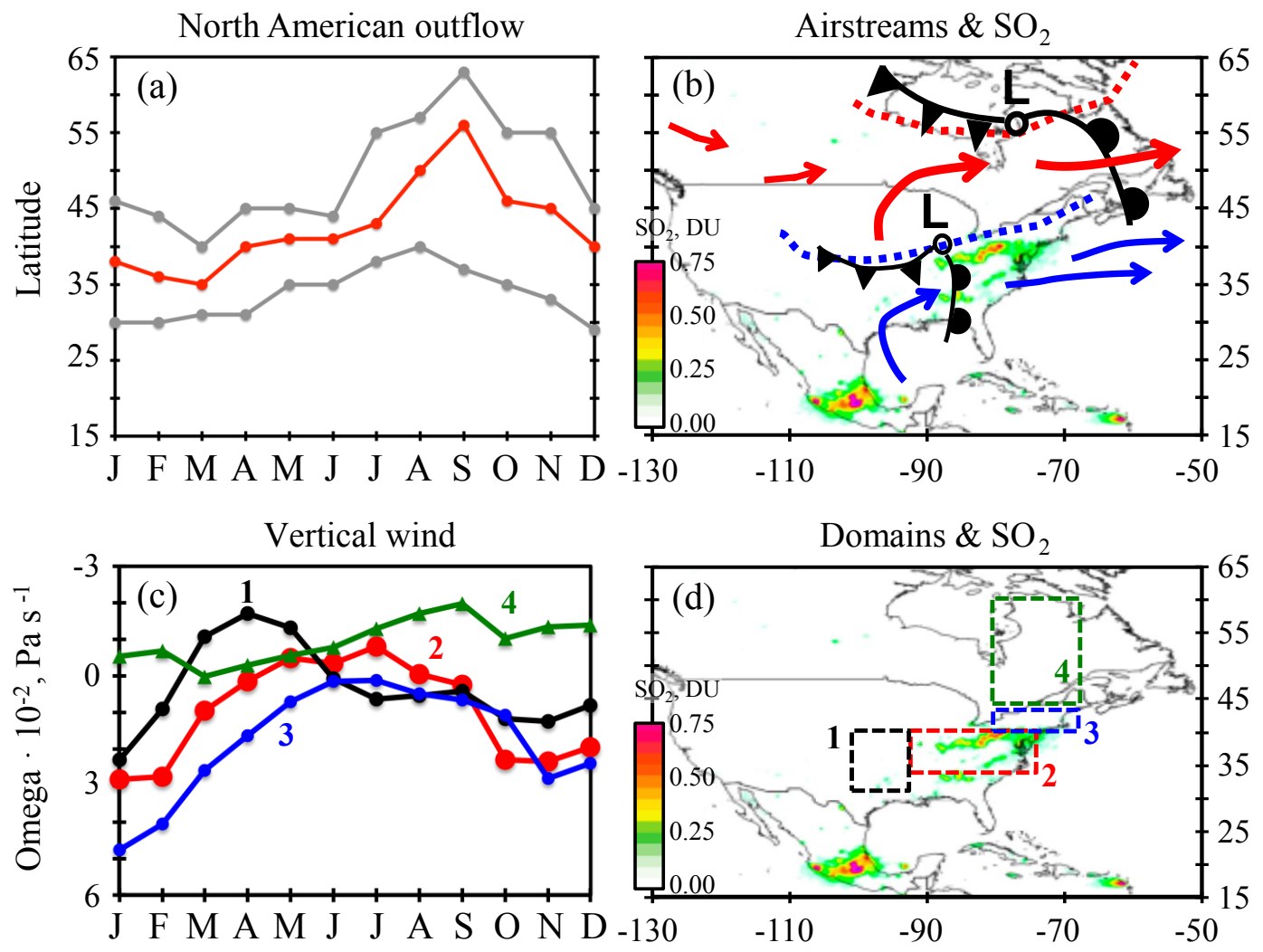

Figure 3. (a) Latitudinal ranges at which the westerlies occurs over the eastern coast of North America. Grey circles: maximum and minimum latitude of the outflow. Red circles: centre of the outflow. (b) Meteorological scenarios associated with export of pollutants (according to Cooper et al., 2002a, b; Merrill and Moody, 1996) and circulations (blue: January-May, red: July-August) illustrated over mean $\mathrm{SO}_{2}$ values observed by satellite by Fioletov et al. (2016) - copyright of the authors. (c) Monthly average values of the omega vertical wind component at the $850 \mathrm{hPa}$ level (negative values indicate upward movements) calculated for the domains illustrated in plot (d). (d) Domains 1 (32-40 $\mathrm{N}$, $\left.90-100^{\circ} \mathrm{W}\right), 2\left(35-40^{\circ} \mathrm{N}, 75-90^{\circ} \mathrm{W}\right), 3\left(40-43^{\circ} \mathrm{N}, 70-80^{\circ} \mathrm{W}\right)$ and $4\left(46-60^{\circ} \mathrm{N}, 70-80^{\circ} \mathrm{W}\right)$.

vatory (23-27 days month ${ }^{-1}$; Fig. 1c1) and has implications for the export of major aerosol components, which have high concentrations in the north-eastern US (Fig. 4).

In July and August, the North Atlantic anticyclone shifts northward (Fig. S2c) resulting in intense trade winds over the Caribbean. The Gulf inflow continues blowing northward across the great plains up to Canada where it connects with the main westerlies jet, whereas southern winds prevail along the eastern coast of the US (Fig. 2a3). In September, the trade winds, the resulting Gulf inflow and southern winds over the eastern coast weaken. In this season, the westerlies and the resulting North American outflow shift northward $\left(45-55^{\circ}\right.$ N; Figs. 2a3-b3, 3a); this is consistent with previous studies showing that cyclone tracks and the resulting warm conveyor belts linked to the export of pollutants tend to occur over Canada (Merrill and Moody, 1996; Cooper et al., 2002a). This scenario is illustrated in Fig. 3b, where the cyclone track is highlighted by a dotted red line and the circulation by the red arrow. This is consistent with the seasonal evolution of the omega vertical wind component, which shows the lowest (negative) values in August and
September in eastern Canada (domain 4 in Fig. 3c and d), indicating upward movements of the North American outflow. At Izaña, the westerlies occur with a minimum frequency in July (12 days) and August (9 days; Fig. 1c1), the period in which the observatory is frequently within the easterly Saharan Air Layer (Rodríguez et al., 2011, 2015). Observe how the air masses from inner North America have a lower impact at Izaña compared to at other periods (Fig. 3b3).

From October to December, the North Atlantic high shifts southward, expanding over the south-eastern US (Fig. S1d). The Gulf inflow weakens and the westerly wind band shifts progressively southward prompting the transport of air from the central US to the North Atlantic (Fig. 2a4-b4).

An overall analysis indicates marked seasonality in the atmospheric circulations with potential implications for the export and transatlantic transport of major aerosol components. The westerlies (Fig. 2a-b), including the North American outflow (Fig. 3), occur at lower (subtropical) latitudes in winter than in summer (midlatitudes). This seasonal shift is also associated with the upward transport of air, which is important in the central and eastern US in March-May (do- 
mains 1 and 2 in Fig. 3c and d) and shifts northward along eastern North America during spring and summer (domains 2 to 4 in Fig. $3 \mathrm{c}$ and d), reaching maximum intensity when the North American outflow occurs over eastern Canada in August and September (domains 4 in Fig. 3d). This affects which source regions of North America impact downwind North Atlantic free troposphere: air masses from southern US are transported across the Atlantic in winter (Fig. 2b1) from the central US in spring (Fig. 2b2) and from Canada in summertime (Fig. 2b3). This is consistent with the seasonal shift of cyclone tracks, westerlies and warm conveyor belt described in previous studies (Stohl, 2001; Cooper et al., 2002a). Of special relevance is spring, when the westerly jet blows over $\mathrm{SO}_{2}$ source regions coupled with upward movements that are able to transport aerosols emitted near ground to altitude above the boundary layer (Fig. 3b).

\subsection{Transatlantic transport of North American aerosols}

We studied the seasonal variability of the sub- $10 \mu \mathrm{m}$ aerosol components under westerly airflow conditions at Izaña and its connection to the transatlantic transport from North America. The chemical composition of 126 samples of $\mathrm{PM}_{10}$ collected at Izaña (2008-2013) under westerly airflow conditions were used (back-trajectories are plotted in Fig. S1a).

Under westerly airflow conditions, the time series of the aerosol components typically show a low background level and sporadic peak episodes; for example, $\mathrm{nss}^{-\mathrm{SO}_{4}}=$ shows a background of $0.05-0.15 \mu \mathrm{g} \mathrm{m}^{-3}$ and peak events $0.5-$ $1.5 \mu \mathrm{g} \mathrm{m}^{-3}$, organic matter increase from $0.01-0.2 \mu \mathrm{g} \mathrm{m}^{-3}$ background level to $1-2.5 \mu \mathrm{g} \mathrm{m}^{-3}$ peak events, whereas elemental carbon has a background $<0.01 \mu \mathrm{g} \mathrm{m}^{-3}$ and peak events within the range $0.03-0.1 \mu \mathrm{g} \mathrm{m}^{-3}$. For each aerosol component, we determined the seasonal evolution of the monthly 30th, 50th and 80th percentiles to be representative of the background levels, central position of concentration distribution and high-concentration episodes respectively. The 30th and 80th percentile plots are presented in the Supplement (Sect. S5). The Median Concentrations at Receptor (MCAR) plots were determined for the study of the connection of peak events of aerosol components at Izaña with episodes of North American aerosol export.

\subsubsection{Sulfate}

Figure 5a1 shows the MCAR plot for nss- $\mathrm{SO}_{4}^{=}$, whereas Fig. 5b1 shows the value of the 50th percentile (50thP) concentration for each month at Izaña. The monthly 50thP of nss- $\mathrm{SO}_{4}^{=}$shows high levels from March to July (0.28$0.41 \mu \mathrm{g} \mathrm{m}^{-3}$ ), with a maximum in March-May (0.33$\left.0.41 \mu \mathrm{g} \mathrm{m}^{-3}\right)$, and low levels from September to February $\left(0.06-0.24 \mu \mathrm{g} \mathrm{m}^{-3}\right)$. The March to July period can be considered the high-sulfate-concentration season, given that both
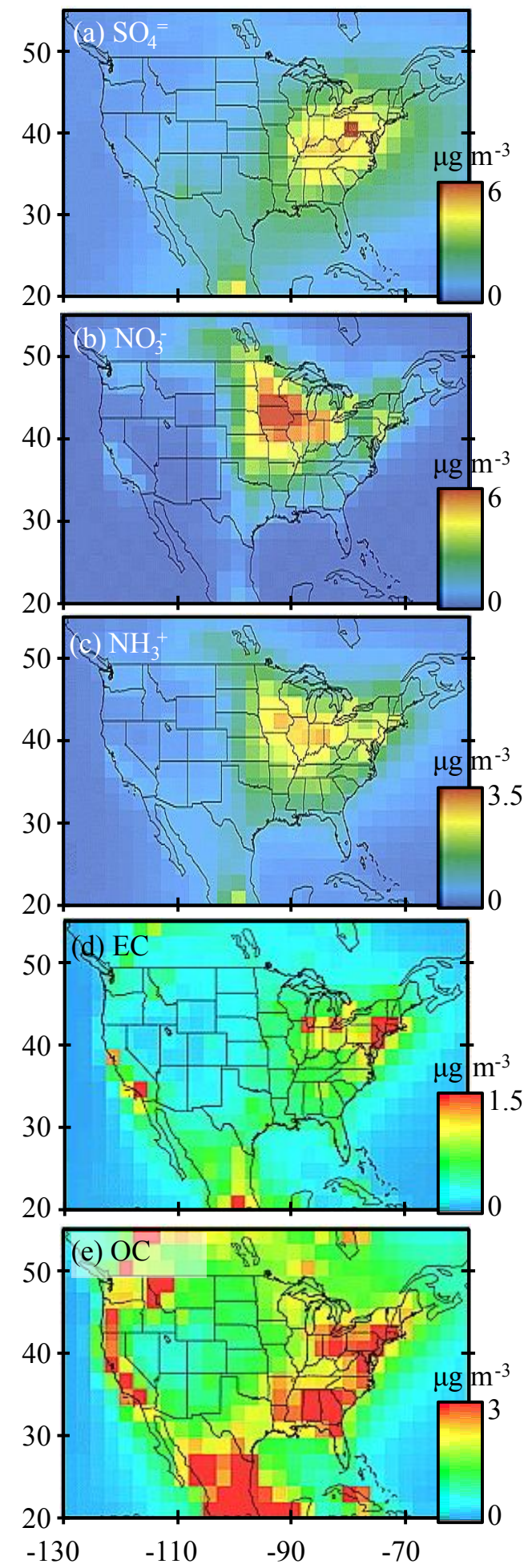

Figure 4. Mean surface concentrations of the (a) $\mathrm{SO}_{4}^{=}$, (b) $\mathrm{NO}_{3}^{-}$, (c) $\mathrm{NH}_{3}^{+}$, (d) EC and (e) OC in North America obtained in previous studies by GEOS-CHEM modelling and validated with the observations in the network IMPROVE (Park et al., 2003,2004, Copyright by the American Geophysical Union). 

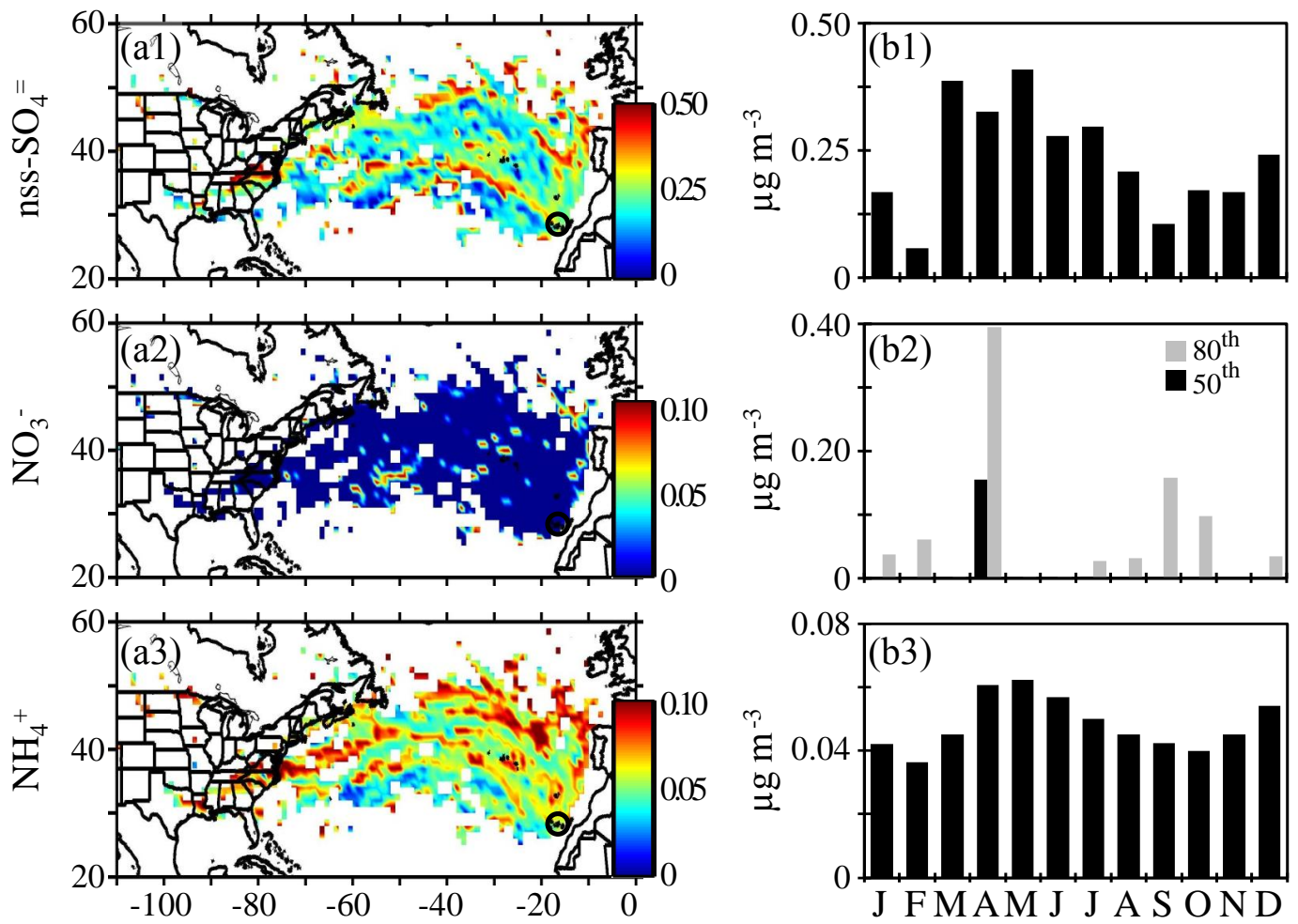

Figure 5. (a) Median Concentration At Receptor (MCAR) plots and (b) monthly median distribution for $\mathrm{nss}^{-\mathrm{SO}_{4}^{=}}, \mathrm{NO}_{3}^{-}$, and $\mathrm{NH}_{4}^{+}$for the study period. Percentiles 50 and 80 are shown for $\mathrm{NO}_{3}^{-}$. The MCAR plots maximum concentration tick label includes concentration higher than this upper limit. The location of Izaña is highlighted (black circle).

the monthly background (30thP) and median (50thP) levels are high in this period (Fig. S5a).

The MCAR plot represents the nss- $\mathrm{SO}_{4}^{=}$concentration recorded at Izaña (median value, i.e. 50thP) when the airflows (tracked by back-trajectories) have passed by each pixel of the study domain (Fig. 5a1). Regions with relatively high nss- $\mathrm{SO}_{4}^{=}$concentrations $\left(0.3-0.5 \mu \mathrm{g} \mathrm{m}^{-3}\right.$ in yellow to red scale) compared to the background $\left(<0.1 \mathrm{\mu g} \mathrm{m}^{-3}\right.$ in blue) are connected to potential transport routes. The MCAR plot suggests that there are two preferential transport paths. The first route points to the transport of nss- $\mathrm{SO}_{4}^{=}$from the north-eastern US at $\sim 40^{\circ} \mathrm{N}$; this is consistent with the high $\mathrm{SO}_{2}$ emissions (Fig. 3b) and high nss-SO $=$ (Fig. 4a) typical of this region (Fig. 3b) that are associated with coal burning power plants (Mann et al., 2010; Fioletov et al., 2011, 2016) and the North American outflow (Fig. 3). Because the North American outflow occurs over this region (NE US) during a great part of the year (Fig. 3), this is probably the most important nss- $\mathrm{SO}_{4}^{=}$export region to the Atlantic. The correlated seasonal evolution of omega in this region (domain 2 in Fig. 3c and d) and nss-SO $=$ at Izaña (Fig. 5b1) indicate enhanced upward movements of air from March to July and enrich the North Atlantic free troposphere in sulfate aerosols. Maximum nss- $\mathrm{SO}_{4}^{=}$occurs from March to May (Fig. 5b1), when upward air movements associated with the
Gulf inflow (Fig. 3), cyclones (Cooper et al., 2002b) and the occurrence of the North American outflow over this region enhances the export of regional pollutants (Figs. 3a and 4a). A second transport pathway is associated with transatlantic transport at higher latitudes $\left(50^{\circ} \mathrm{N}\right)$ and anticyclonic circulation around the Azores High (Fig. 5a1); this route is associated with the occurrence of the North American outflow over the northern US and Canada, from midsummer (August) to mid-autumn (November; Fig. 3a1). Observe how the drop in the median (50thP: from 0.30 to $0.20 \mu \mathrm{g} \mathrm{m}^{-3}$, Fig. S5a2) and of the background (30thP: from 0.26 to $0.16 \mu \mathrm{g} \mathrm{m}^{-3}$; Fig. S5a3) nss- $\mathrm{SO}_{4}^{=}$concentrations from July to August is associated with the northward shift of the main westerly stream and the North American outflow (Fig. 3a1). From August on the westerly jet occurs at higher latitudes over Canada, in regions with less nss- $\mathrm{SO}_{4}^{=}$compared to NE US (Fig. 4a). As a result less nss- $\mathrm{SO}_{4}^{=}$is exported and transported across the Atlantic.

\subsubsection{Nitrate}

The MCAR plot and the monthly 50thP of $\mathrm{NO}_{3}^{-}$at Izaña are plotted in Fig. 5a2 and b2. Nitrate was present in extremely low concentrations most of the time. Concentrations were $<0.05 \mu \mathrm{g} \mathrm{m}^{-3}$ in 97 samples, and $>0.1 \mu \mathrm{g} \mathrm{m}^{-3}$ in only 21 samples. For this reason the 50 thP was $\sim$ zero 

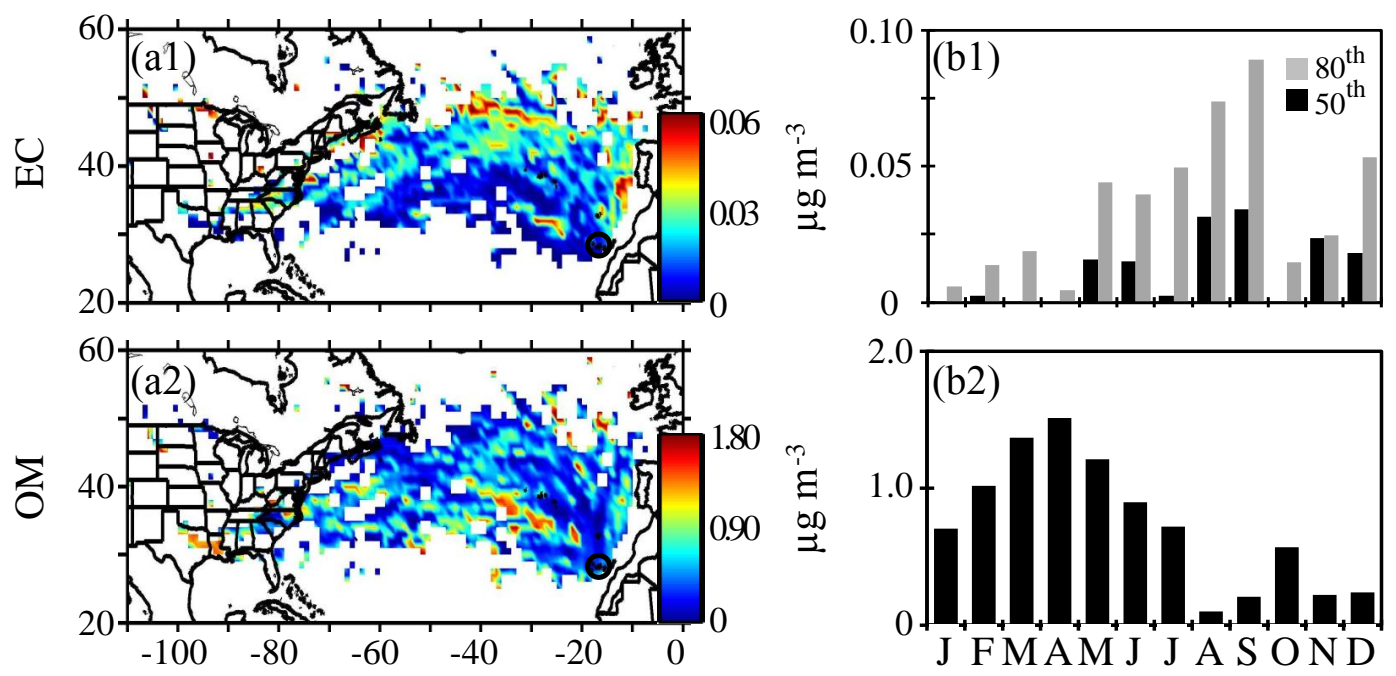

Figure 6. (a) Median Concentration At Receptor (MCAR) plots and (b) monthly median distribution for elemental carbon (EC) and organic matter (OM) for the study period. Percentiles 50 and 80 are shown for EC. The MCAR plots maximum concentration tick label includes concentration higher than this upper limit. The location of Izaña is highlighted (black circle).

for most months (Fig. 5b2). High $\mathrm{NO}_{3}^{-}$concentration events (80thP $>0.1 \mu \mathrm{g} \mathrm{m}^{-3}$ ) were mostly recorded in winter and early spring (January-April, Fig. 5b2), when high $\mathrm{NO}_{3}^{-}$ was within the range $0.2-0.8 \mu \mathrm{g} \mathrm{m}^{-3}$. This is typical behaviour for ammonium nitrate, which mostly forms under low temperature conditions, whereas gaseous nitric acid prevails in warmer environments (Squizzato et al., 2013). The MCAR plot shows transport of $\mathrm{NO}_{3}^{-}$at low latitudes 30$35^{\circ} \mathrm{N}$ (Fig. 5a2), which is consistent with the circulation of the westerlies (e.g. Fig. 2a1 and b1) and the North American outflow in winter months (e.g. Fig. 3a1), when most of the above-described high $\mathrm{NO}_{3}^{-}$events occur (Fig. 5b2). High concentrations of nitrate in North America occur in the central northern region (Fig. 4b), where conditions favourable for the formation of ammonium nitrate occur (US EPA, 2000; Park et al., 2004): (i) enough high concentrations of gas phase precursors $\left(\mathrm{NH}_{3}\right.$ linked to emissions in agriculture fields treated with fertilisers and $\mathrm{HNO}_{3}$ due to oxidation of $\mathrm{NO}_{x}$ linked to fossil fuel combustion) and (ii) suitable thermodynamic conditions (rather low temperature and enough high relative humidity). Our results suggest that nitrate export events from North America may be associated with NW winds (e.g. as the main stream of the westerlies in winter, Fig. 2a1) over this high-nitrate region (Fig. 4b) followed by export at $35-30^{\circ} \mathrm{N}$ (Fig. 5b1) under geopotential/pressure systems that should be studied in future research. The MCAR plot also suggests a second transport route similar to that observed for nss- $\mathrm{SO}_{4}^{=}$, i.e. transatlantic transport at high latitudes $\left(50^{\circ} \mathrm{N}\right)$ and circulation around the Azores High (Fig. 5b1) which is probably associated with the autumn events (Fig. 5b2), when the North American outflow occurs over Canada (Fig. 3a1). The nitrate concentrations we observe at Izaña are similarly low to those registered by Dzepina et al. (2015) at the Pico free troposphere site in the Azores linked to long-range transport from North America. Because nitrate may experience negative artefacts during sampling (Schaap et al., 2004; Vecchi et al., 2009), we cannot discard underestimations. Further online nitrate measurements (e.g. using an Aerosol Chemical Speciation Monitor) should be included in the long-term aerosol measurements programme.

\subsubsection{Ammonium}

The MCAR plot and the monthly 50thP of $\mathrm{NH}_{4}^{+}$at Izaña are shown in Fig. 5a3 and b3. Median (50thP) and 80thP concentrations present a maximum in April-May (Fig. 5b3 and c1), as nss- $\mathrm{SO}_{4}^{=}$. The MCAR plot for $\mathrm{NH}_{4}^{+}$shows two main transport pathways which resemble those of nss- $\mathrm{SO}_{4}^{=}$: one transport pathway from the north-eastern US at $\sim 40^{\circ} \mathrm{N}$ and a second transport route pointing to the occurrence of the North American outflow by Canada and subsequent transatlantic transport at high latitudes and circulation around the Azores High (Fig. 5a3). Because of the prevalent extremely low levels of nitrate, ammonium is attributed to ammonium sulfate in most events. The transport (north-eastward export) routes we observe for nss- $\mathrm{SO}_{4}^{=}$and $\mathrm{NH}_{4}^{+}$in the eastern US (Alabama, Tennessee and Virginia; Fig. $5 \mathrm{a} 1$ and a3) are similar to those associated with the passage of spring cyclones and front in the region, prompting the export of pollutants to the Atlantic (Cooper et al., 2002b).

\subsubsection{Elemental carbon}

Figure $6 \mathrm{a} 1$ and $\mathrm{b} 1$ shows the MCAR plot and the monthly 50thP and 80thP of EC. The analysis of the monthly 50thP and 80thP values discloses two relevant periods, associated to 
high (May-September) and low (January-April) EC events. We associated this seasonal variability of the EC transported by the westerlies to Izaña (i) with the spatial distribution of the EC source regions in North America (Fig. 4d) and (ii) with the seasonal shift of the westerlies (Fig. 2a1-a4) and the North American outflow (Fig. 3). The highest surface concentrations of EC are estimated to occur in what we have called "EC-rich NE US regions", which include large urban areas placed $40-45^{\circ} \mathrm{N}$ south of the great lakes to the Atlantic coast (e.g. Chicago, Detroit, New Jersey, Philadelphia and New York; Fig. 4d), linked to fossil fuel combustion (mostly diesel exhaust emissions and coal burning) according to Park et al. (2003).

The season of high EC concentrations at Izaña occurs from May to September, when the westerlies shift northward from 40 to $55^{\circ} \mathrm{N}$ (Fig. 3a) affecting the EC-rich NE US regions $\left(40-45^{\circ} \mathrm{N}\right.$, Chicago to New York, Fig. 4d). This seasonal shift is associated with a rise of the upward air movements in the eastern US (domains 2 and 3 in Fig. $3 c$ and d), including the EC-rich NE US regions (domain 3 in Fig. 3c and d), that enhances the export of EC to the North Atlantic free troposphere in the North American outflow. The highest median EC concentrations at Izaña are observed in August and September $\left(\sim 0.03 \mu \mathrm{g} \mathrm{m}^{-3}\right.$; Figs. $\left.6 \mathrm{~b} 1, \mathrm{~S} 5 \mathrm{~d} 1\right)$, when the eastward-propagating cyclones over Canada prompt the export of pollutants from these EC-rich NE US regions to the Gulf of Maine and the Atlantic (Merrill and Moody, 1996), in a scenario illustrated in Fig. 3b. The lowest values of omega in eastern Canada (domain 4 in Fig. 3c and d) occur in August and September, which indicates a great potential to lift boundary layer air to the North Atlantic free troposphere. This interpretation is consistent with the MCAR plot for EC, which shows a clear transport pathway (at high latitudes, $\sim 50^{\circ} \mathrm{N}$ ) from Canada and these EC-rich NE US regions to the Gulf of Maine and then to the Atlantic with subsequent circulation around the Azores High (Fig. 6a1); this EC transport route is similar to the prevalent transport pathway of $\mathrm{Au}$ gust and September (Fig. 2b3).

Low EC concentrations at Izaña occur between January and April, when the westerlies and the North American outflow occur at low latitudes $\left(<40^{\circ} \mathrm{N}\right.$; Fig. 3a), to the south of the EC source regions $\left(40-45^{\circ} \mathrm{N}\right.$; Fig. $\left.4 \mathrm{~d}\right)$.

Figure 7 shows the mean burnt fraction (\%) of each $0.25^{\circ} \times 0.25^{\circ}$ grid cell associated with fires, which occur mainly in the south-eastern US in January-February (Fig. 7a). They then spread northward from March on from the central US to southern Canada (Fig. 7b) and over Canada and the NW US in June-September (Fig. 7c) and then shift southward to the US (Fig. 7d). Boreal fires prompt high EC concentrations in Canada (Park et al., 2005) in the NW and north-central US (Washington, Oregon and Nevada; Park et al., 2003) that can be exported to the Atlantic in the uplifting North American outflow, potentially contributing to the EC records at Izaña in August and September (Fig. 6b1).
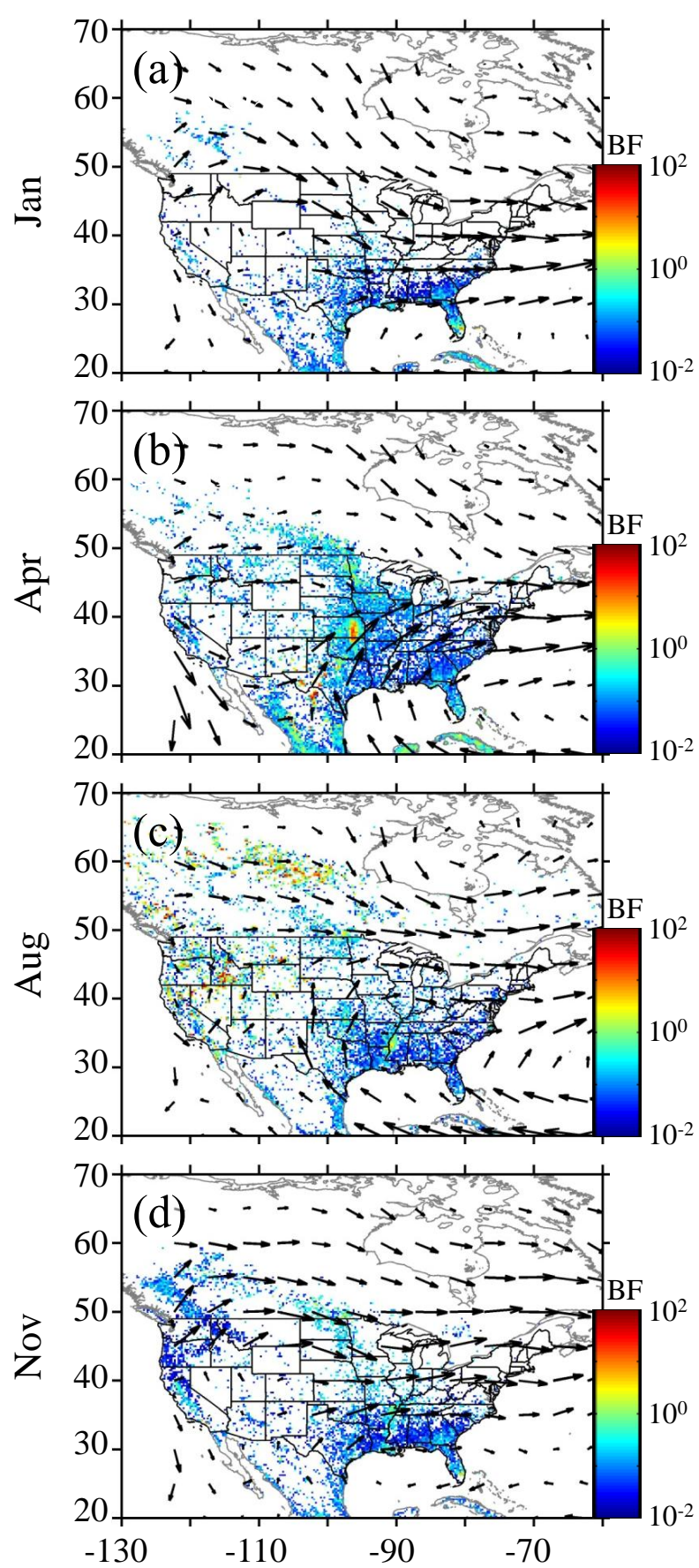

Figure 7. Burned fraction $(\mathrm{BF})$ of each $0.25^{\circ} \times 0.25^{\circ}$ grid cell and vector wind at $850 \mathrm{mb}$ averaged from 2008 to 2013 for (a) January, (b) April, (c) August and (d) November. The Global Fire Emissions Database Version 4 including small fires data (GFEDv4.1s; Randerson et al., 2015) was downloaded from the Oak Ridge National Laboratory Distributed Active Archive Centre (ORNL DAAC) for biogeochemical dynamics (https://daac.ornl.gov/cgi-bin/dsviewer. pl?ds_id=1293). 

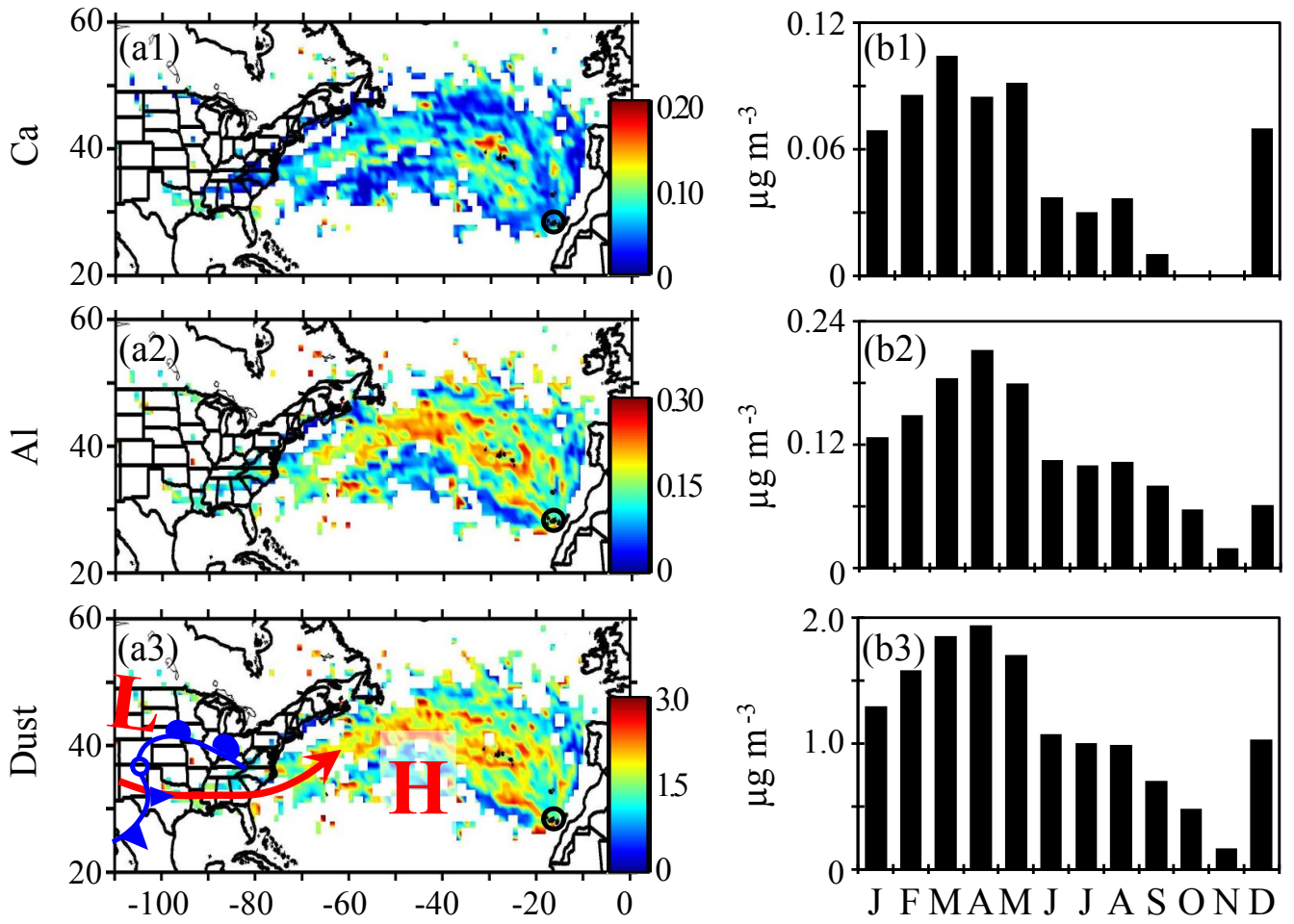

Satellite dust observations
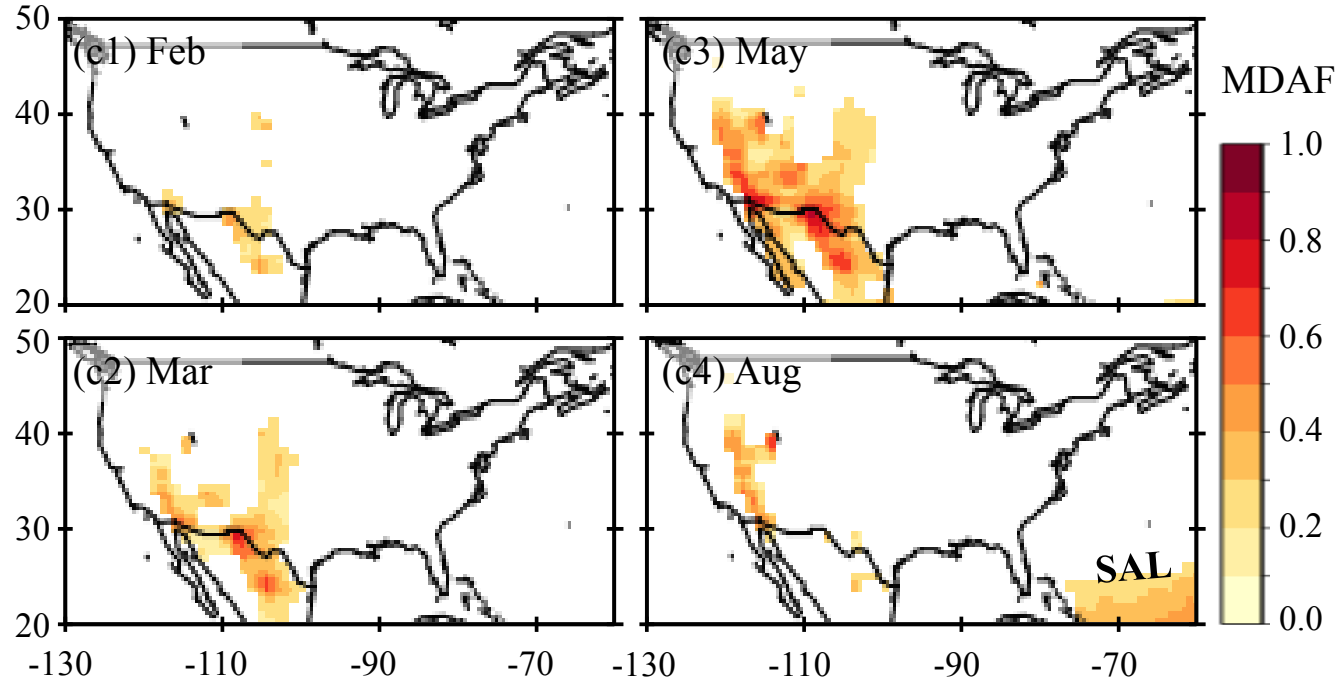

0.6

0.4

0.2

Figure 8. (a) Median Concentration At Receptor (MCAR) plots and (b) monthly median distribution for calcium (Ca), aluminium (Al) and dust, and (c) major dust activity frequency (MDAF) for the study period: the number of days with AI values $>1$ divided by the total number of days with available AI data in \% (data source: http://disc.sci.gsfc.nasa.gov/). The maximum concentration tick label of the MCAR plots includes concentration higher than this upper limit. The location of Izaña is highlighted (black circle).

\subsubsection{Organic matter}

Figure $6 \mathrm{a} 2$ and $\mathrm{b} 2$ show the MCAR plot and the monthly 50 thP of OM. This aerosol component shows very marked seasonal evolution, with high levels from January to July, and a maximum from March to May (Figs. 6b2, S5e1-e3).
This is consistent with the MCAR plot (Fig. 6a2), which shows a transport route from the south-eastern US to Izaña at low latitudes $\left(30-40^{\circ} \mathrm{N}\right)$, a common circulation of winter and spring (Fig. 2a1-a2). From August to December, OM concentrations transported by the westerlies to Izaña are low, 

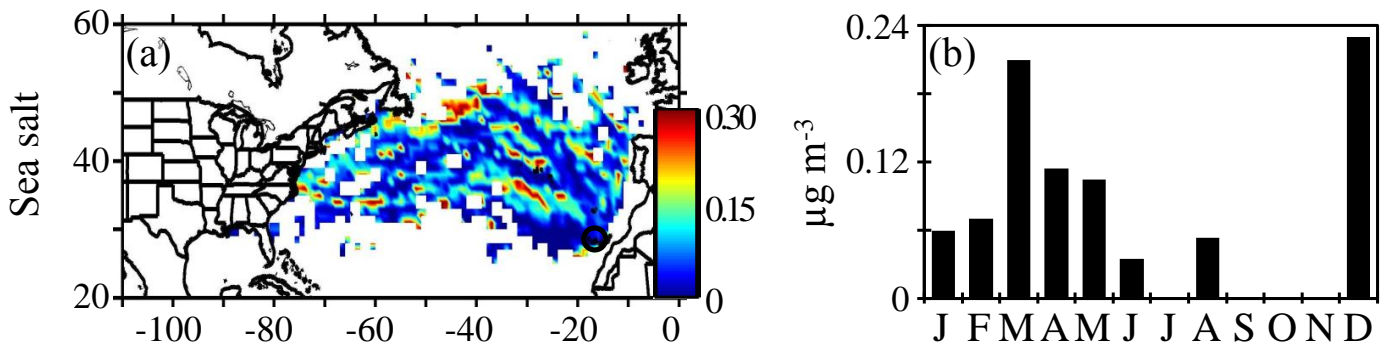

Figure 9. (a) Median Concentration At Receptor (MCAR) plots and (b) monthly median distribution for sea salt for the study period. The MCAR plots maximum concentration tick label includes concentration higher than this upper limit. The location of Izaña is highlighted (black circle).

associated with the occurrence of the westerlies over North America at high latitudes (Fig. 2a3-a4).

The seasonal evolution of $\mathrm{OM}$ is very different (almost the opposite) to that of EC (Fig. 6a2 and b2). Air masses transported from the south-eastern US to Izaña (January to April) are rich in OM and relatively poor in EC (Fig. 6a2 and b2), whereas the air transported from NE US to Izaña (typically from July to September) is poor in OM and rich in EC (Fig. $6 \mathrm{a} 2$ and b2). This is consistent with the spatial distribution of these aerosol species in the US (Fig. 4d and e) and suggests that in the south-eastern US there is a significant contribution to OM of sources that are not related to combustion, but probably to biogenic emissions (Millet et al., 2008). Previous studies estimated the contribution of biogenic SOA to $\mathrm{OM}$ to be within the range $50-60 \%$ in the south-eastern US (Blanchard et al., 2016; Kim et al., 2015; Ying et al., 2015). Globally, about half of biogenic volatile organic carbon emissions (BVOCs) are SOA precursors, i.e. isoprene $(\sim 50 \%)$ and $\alpha$-pinene $(\sim 7 \%)$ (Guenther et al., 2012). Biogenic emissions are among the principal sources of OM in the US, followed by three combustion sources that also emit EC (wildfires, fossil fuels and biofuel) (Park et al., 2003). Particularly in the south-eastern US, BVOC emissions are mainly isoprene ( $81 \%$ ) and monoterpenes (19\%) (Goldstein et al., 2009). A scenario of biogenic emissions higher in the SE US than in the NE US is consistent with the global distribution of the secondary organic aerosols, the concentrations of which are usually higher near to the tropics than at midlatitudes (Guenther et al., 2012; Sindelarova et al., 2014). The importance of the spatial variability of the OM and EC sources and the latitudinal shift of the westerlies over eastern North America is illustrated from July to August, when a drop in OM concentrations ( 0.85 to $0.20 \mu \mathrm{g} \mathrm{m}^{-3}$; Fig. 6b2) and an increase in EC concentrations ( 0.005 to $0.03 \mu \mathrm{g} \mathrm{m}^{-3}$; Fig. 6b1) is associated with the northern shift of the North American outflow (43 to $50^{\circ} \mathrm{N}$; Fig. 3a).

\subsubsection{Mineral dust}

Figure $8 \mathrm{a}$ and $\mathrm{b}$ show the MCAR plot and the monthly 50thP of calcium, aluminium and the associated bulk dust con- centrations. These aerosol components exhibit high concentrations from February to May (Figs. 8b1-b3, S5f-h). The MCAR plot shows a pattern of North American dust export at low latitudes $\left(\sim 35^{\circ} \mathrm{N}\right.$, through North Carolina) towards the north-east which, once over the Atlantic, follow the anticyclonic circulation around the Azores High to Izaña (Fig. 8a1a3). We attribute these events to dust emissions in a region that expands from SW Texas northward throughout the High Plains, and subsequent dust export to the Atlantic. Figure $8 \mathrm{c}$ shows the major dust activity frequency (MDAF) detected by satellite: dust activity is observed in SW Texas (Chiguagua and Big Bend Desert) in February. Through March to May the activity expands northward across the High Plains (western Texas to Nebraska); other dust sources with lower potential for impact on the North Atlantic are also observed in the western US (Great Basin, Mojave Desert and Colorado Plateau). The High Plains are among the major dust sources in North America, and these sources are considered anthropogenic (linked to agriculture), with maximum activity between February and May (Ginoux et al., 2012). Dust emissions and eastward mobilisation are associated with the intense westerly winds linked to eastward-moving cyclones, which also prompt the upward transport of dust to several kilometres above the ground, according to Novlan et al. (2007); this scenario is illustrated in Fig. 8a3, showing that the associated air mass track is consistent with the dust export and transatlantic transport route to Izaña observed in our analysis. During these spring events high dust concentrations (100s of $\mu \mathrm{g} \mathrm{m}^{-3}$ ) are lifted to altitudes $6-12 \mathrm{~km}$ a.s.l. over southern US (Talbot et al., 1998). Upward transport of dust is also associated with convective activity in the central US, Colorado and Oklahoma, in May-June (Corr et al., 2016). The correlation we found between the seasonal evolution of omega in domain 1 (Fig. $3 \mathrm{c}$ and d) and dust at Izaña (Fig. 8b3) supports the idea that from February to May westerly winds and the uplifting of air in the High Plains enrich the North American outflow and the westerly jet in the in dust aerosols. 

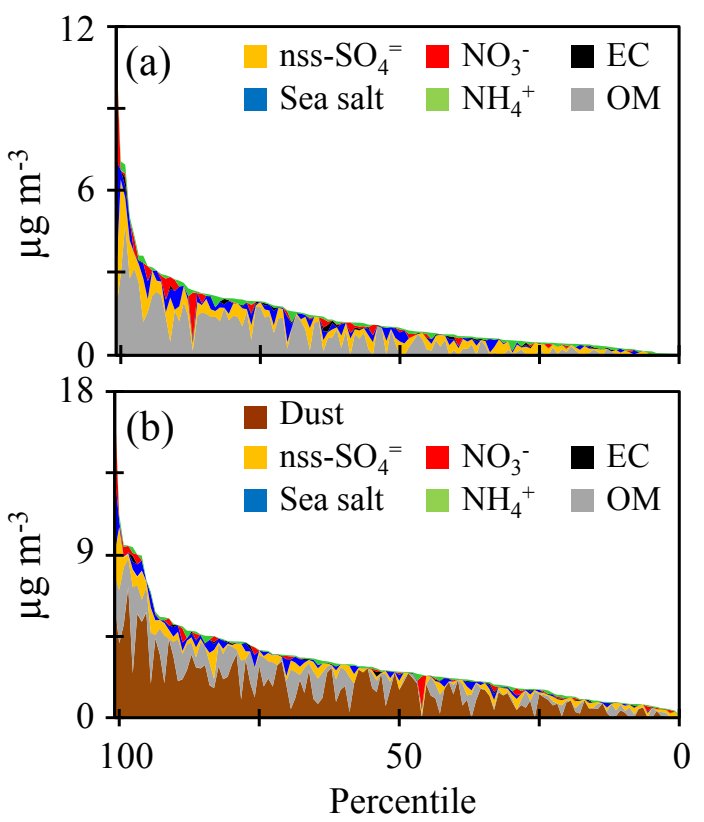

Figure 10. Contribution of each aerosol specie to bulk $\mathrm{PM}_{10}$ in samples collected at Izaña under westerly airflow conditions; data classified from the highest to the lowest levels. (a) Considering major components except dust. (b) Considering all major components including mineral dust.

\subsubsection{Sea salt}

Sea salt concentrations at Izaña are extremely low, with monthly 50thP values 0.07 to $0.22 \mu \mathrm{g} \mathrm{m}^{-3}$ between December and May (Fig. 9). These low concentrations are typical of free troposphere sites; in fact, sea salt at Izaña (average $=0.25 \mu \mathrm{g} \mathrm{m}^{-3}$, median $0.16 \mu \mathrm{g} \mathrm{m}^{-3}$ ) is about 2 orders of magnitude lower than in the marine boundary layer of the $\mathrm{Ca}$ nary Islands (average $\sim 11 \mu \mathrm{g} \mathrm{m}^{-3}$, Querol et al., 2004). The extremely low concentrations of this marine aerosol at Izaña supports our interpretations; i.e. the aerosols transported by the westerlies to Izaña are mostly linked to emissions and upward transport in continental regions of North America, and not over the ocean.

\subsubsection{Mass closure of aerosols}

Figure 10 shows the contribution of each species to bulk $\mathrm{PM}_{10}$ aerosol mass in samples collected in the westerlies at Izaña. Data are classified from the highest to the lowest levels. We considered two approaches: including and excluding mineral dust. When mineral dust is not included (Fig. 10a), the most important contributors to bulk $\mathrm{PM}_{10}$ are by far nss$\mathrm{SO}_{4}^{=}$and $\mathrm{OM}$. In the 1st-50th percentile range for the sum of aerosol components (a proxy of background levels) -0.05 to $1.0 \mu \mathrm{g} \mathrm{m}^{-3}$ - the most important contributors are nss- $\mathrm{SO}_{4}^{=}$ $\left(0.19 \mu \mathrm{g} \mathrm{m}^{-3}\right.$ on average, accounting for $38 \%$ of the sum of chemical species) and $\mathrm{OM}\left(0.14 \mu \mathrm{g} \mathrm{m}^{-3}, 30 \%\right)$. In the $75 \mathrm{st}-$ 95th percentile range (a proxy of high load of aerosol events) $-\sim 2.0$ to $3.6 \mu \mathrm{g} \mathrm{m}^{-3}$ - the most important contributors are $\mathrm{OM}\left(1.43 \mu \mathrm{g} \mathrm{m}^{-3}, 57 \%\right)$ and nss-SO $=\left(0.48 \mu \mathrm{g} \mathrm{m}{ }^{-3}, 19 \%\right)$. These results are consistent with previous studies that did not include dust, such as Park et al. (2004, 2005), who focused on the composition of aerosols in the background boundary layer of US, and Dzepina et al. (2015), who studied the aerosols transported from North America to the North Atlantic free troposphere at Pico observatory in the Azores.

When mineral dust is considered, it becomes the most important contributor to sub-10 $\mu$ m aerosol mass (Fig. 10b). In the 1st-50th percentile range (a proxy of background levels), bulk $\mathrm{PM}_{10}=0.15-2.54 \mu \mathrm{g} \mathrm{m}^{-3}$, the most important contributors to bulk aerosol mass are dust $\left(0.78 \mathrm{\mu g} \mathrm{m}^{-3}\right.$ on average, accounting for $53 \%$ of bulk mass), nss-SO $=\left(0.21 \mu \mathrm{g} \mathrm{m}^{-3}\right.$, $14 \%), \mathrm{OM}\left(0.27 \mu \mathrm{g} \mathrm{m}^{-3}, 18 \%\right)$ and $\mathrm{NH}_{4}^{+}\left(0.07 \mu \mathrm{g} \mathrm{m}^{-3}\right.$, $5 \%$ ). In the 75th-95th percentile range (a proxy of aerosol events), bulk $\mathrm{PM}_{10}=3.9-8.9 \mu \mathrm{g} \mathrm{m}^{-3}$. The most important contributors to bulk aerosol mass are dust $\left(2.8 \mu \mathrm{g} \mathrm{m}^{-3}\right.$, $56 \%)$ and $\mathrm{OM}\left(1.23 \mu \mathrm{g} \mathrm{m}^{-3}, 24 \%\right)$ followed by nss-SO $\left(0.47 \mu \mathrm{g} \mathrm{m}^{-3}, 9 \%\right)$ and $\mathrm{NH}_{4}^{+}\left(0.1 \mu \mathrm{g} \mathrm{m}^{-3}, 2 \%\right)$. The lack of previous studies on transatlantic transport of North American dust make the comparison with previous data difficult; it should be highlighted that Ancellet et al. (2016) detected this transatlantic transport in June (out of the seasonal maximum). Environmental studies have shown that the conversion of natural lands to agriculture and pasturage fields has had a number of impacts in North America (Nordstrom and Hotta, 2004; Wu and Cho, 2007). Moreover, research has predicted that this change of land use may increase (MNP, 2006; Lawler et al., 2014), and this suggests an enhancement of dust impacts in downwind regions.

Our overall results provide evidence that dust and organic matter are the most abundant aerosols transported from North America to the North Atlantic free troposphere.

\section{Conclusions}

A $\sim 5$-year record of aerosol chemistry at Izaña Observatory (located at $\sim 2400 \mathrm{~m}$ a.s.l. in Tenerife, the Canary Islands) was used to study the transatlantic transport of aerosols. This study shows that North America is a major source of aerosols, which are transported by the westerly winds across the North Atlantic free troposphere at subtropical latitudes and midlatitudes. The composition of aerosols carried by the westerlies experiences a marked seasonal evolution which is influenced by (i) the spatial distribution of the aerosol sources in North America and (ii) the seasonal variability of the large-scale meteorology in North America. Of special meteorological relevance is the seasonal shift in the westerly jet and the North American outflow, which migrate from low latitudes in winter $\left(\sim 32^{\circ} \mathrm{N}\right.$, January-March) to high latitudes in summer $\left(\sim 52^{\circ} \mathrm{N}\right.$, August-September). The export of boundary layer air laden in aerosols to the North Atlantic 
free troposphere is enhanced by the occurrence of cyclones that move eastward with the westerly atmospheric circulation.

We found that the westerlies carry high loads of the following:

- mineral dust from February to May, associated with dust emissions in a region that expands from SW Texas (Chiguagua and Big Bend Desert) northward through the High Plains (western Texas to Nebraska), and subsequent dust export to the Atlantic associated with eastward moving cyclones, westerly winds and the North American outflow, which in this period migrate from $35^{\circ} \mathrm{N}$ in February to $40^{\circ} \mathrm{N}$ in May,

- non-sea-salt sulfate and ammonium from March to May, when cyclones and the associated outflow occur over the north-eastern US, where the highest $\mathrm{SO}_{2}$ emissions occur in North America;

- organic matter from February to May, when cyclones and the associated outflow occur over regions of the eastern US rich in organic aerosols according to previous studies,

- elemental carbon in August and September, when cyclones, the westerly jet and the North American outflow occur at high latitudes $\left(50\right.$ to $55^{\circ} \mathrm{N}$ ) favouring the export of boundary layer air from the regions where the highest concentrations of elemental carbon occur in North America according to previous studies (Chicago to New York, $\left.40-45^{\circ} \mathrm{N}\right)$.

The concentrations of sub- $10 \mu \mathrm{m}$ aerosol mass $\left(\mathrm{PM}_{10}\right)$ that reach Izaña Observatory after transatlantic transport typically range between 1.2 and $4.23 \mu \mathrm{g} \mathrm{m}^{-3}$ (20th and 80th percentiles). The most important contributors to background aerosols (when $\mathrm{PM}_{10}$ is within the 1st-50th percentiles $=0.15-2.54 \mu \mathrm{g} \mathrm{m}^{-3}$ ) are North American dust $(53 \%)$, organic matter $(18 \%)$ and non-sea-salt $\mathrm{SO}_{4}^{=}(14 \%)$. High $\mathrm{PM}_{10}$ events (75th-95th percentiles $=3.9-8.9 \mu \mathrm{g} \mathrm{m}^{-3}$ ) are prompted by dust (56\%), organic matter $(24 \%)$ and nss$\mathrm{SO}_{4}^{=}(9 \%)$. Our results suggest that a significant fraction of organic aerosols may be linked to sources other than combustion (e.g. biogenic) and that North American dust may be linked to anthropogenic dust sources linked to the use of soil.

The overall results indicate that future long-term evolution of the aerosol composition in the North Atlantic free troposphere will be influenced not only by air quality policies applied in urban and industrial areas, but also by the use of potential dust emitter soils in North America, especially those lands linked to agriculture and pasturage activities. These dust emissions should be considered in the regulations on air quality and climate change mitigation.
Data availability. Data of $\mathrm{PM}_{x}$ chemical composition are available from the authors upon request.

The Supplement related to this article is available online at https://doi.org/10.5194/acp-17-7387-2017-supplement.

Competing interests. The authors declare that they have no conflict of interest.

Acknowledgements. This study is part of the project AEROATLAN (CGL2015-66299-P), funded by the Ministry of Economy and Competitiveness of Spain and the European Regional Development Fund (ERDF). The long-term records of the GAW aerosol programme are also funded by AEMET. M. Isabel García acknowledges the grant of the Canarian Agency for Research, Innovation and Information Society (ACIISI) co-funded by the European Social Funds. The authors gratefully acknowledge the NOAA/ESRL Physical Sciences Division for the provision of the NCAR/NCEP reanalysis; NILU for providing FLEXTRA backtrajectories based on meteorological data provided from ECMWF (European Centre for Medium Range Weather Forecast); the BSC (Barcelona Supercomputing Centre) for providing DREAM8b model; the Oak Ridge National Laboratory (ORNL) Distributed Active Archive Centre (DAAC), part of the NASA Earth Observing System Data and Information System (EOSDIS), for providing the Global Fire Emissions Database; the GES-DISC Interactive Online Visualization ANd aNalysis Infrastructure (Giovanni), part of the NASA's Goddard Earth Science (GES) Data and Information Service Centre (DISC), for the OMI AI data set; and the Storm Prediction Centre, part of the NOAA National Weather service, for providing the Severe Weather Database Files for US tornadoes. We also thank to Juan José Bustos for the calculation of the back-trajectories, Javier López-Solano for his assistance with the Aerosol Index data processing and Yvonne Boose for providing the picture of the Saharan Air Layer conditions. The excellent work performed by the staff of Izaña Observatory (Concepción Bayo, Cándida Hernández, Fernando de Ory, Virgilio Carreño, Rubén del Campo and SIELTEC Canarias) is appreciated.

Edited by: Lynn M. Russell

Reviewed by: three anonymous referees
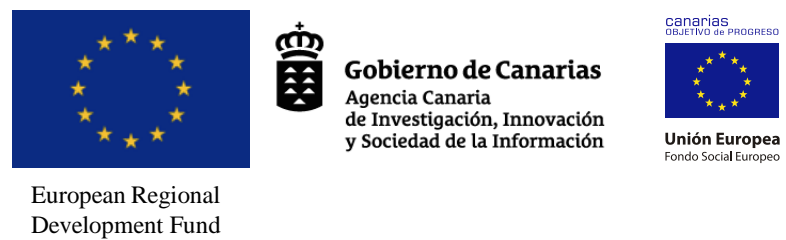

Development Fund 


\section{References}

Ancellet, G., Pelon, J., Totems, J., Chazette, P., Bazureau, A., Sicard, M., Di Iorio, T., Dulac, F., and Mallet, M.: Longrange transport and mixing of aerosol sources during the 2013 North American biomass burning episode: analysis of multiple lidar observations in the western Mediterranean basin, Atmos. Chem. Phys., 16, 4725-4742, https://doi.org/10.5194/acp16-4725-2016, 2016.

Basart, S., Pérez, C., Nickovic, S., Cuevas, E., Schulz, M., and Baldasano, J. M.: Development and evaluation of BSCDREAM8b dust regional model over Northern Africa, the Mediterranean and the Middle East regions, Tellus B, 64, 18539, https://doi.org/10.3402/tellusb.v64i0.18539, 2012.

Blanchard, C. L., Hidy, G. M., Shaw, S., Baumann, K., and Edgerton, E. S.: Effects of emission reductions on organic aerosol in the southeastern United States, Atmos. Chem. Phys., 16, 215238, https://doi.org/10.5194/acp-16-215-2016, 2016.

Bonsang, B., Nguyen, B. C., Gaudry, A., and Lambert, G.: Sulfate enrichment in marine aerosols owing to biogenic gaseous sulfur compounds, J. Geophys. Res.-Oceans, 85, 7410-7416, https://doi.org/10.1029/JC085iC12p07410, 1980.

Cavalli, F., Viana, M., Yttri, K. E., Genberg, J., and Putaud, J.-P.: Toward a standardised thermal-optical protocol for measuring atmospheric organic and elemental carbon: the EUSAAR protocol, Atmos. Meas. Tech., 3, 79-89, https://doi.org/10.5194/amt-3-792010, 2010.

Chai, M., Birch, M. E., and Deye, G.: Organic and elemental carbon filter sets: preparation method and interlaboratory results, Ann. Occup. Hyg., 56, 959-967, https://doi.org/10.1093/annhyg/mes029, 2012.

Chin, M., Diehl, T., Ginoux, P., and Malm, W.: Intercontinental transport of pollution and dust aerosols: implications for regional air quality, Atmos. Chem. Phys., 7, 5501-5517, https://doi.org/10.5194/acp-7-5501-2007, 2007.

Cooper, O. R., Moody, J. L., Parrish, D. D., Trainer, M., Holloway, J. S., Hübler, G., Fehsenfeld, F. C., and Stohl, A.: Trace gas composition of midlatitude cyclones over the western North Atlantic Ocean: A seasonal comparison of $\mathrm{O}_{3}$ and $\mathrm{CO}$, J. Geophys. Res., 107, 4057, https://doi.org/10.1029/2001JD000902, 2002a.

Cooper, O. R., Moody, J. L., Parrish, D. D., Trainer, M., Ryerson, T. B., Holloway, J. S., Hübler, G., Fehsenfeld, F. C., and Evans, M. J.: Trace gas composition of midlatitude cyclones over the western North Atlantic Ocean: A conceptual model, J. Geophys. Res., 107, 4056, https://doi.org/10.1029/2001JD000901, 2002b.

Corr, C. A., Ziemba, L. D., Scheuer, E., Anderson, B. E., Beyersdorf, A. J., Chen, G., Crosbie, E., Moore, R. H., Shook, M., Thornhill, K. L., Winstead, E., Lawson, R. P., Barth, M. C., Schroeder, J. R., Blake, D. R., and Dibb J. E.: Observational evidence for the convective transport of dust over the Central United States, J. Geophys. Res.-Atmos., 121, 1306-1319, https://doi.org/10.1002/2015JD023789, 2016.

Dickerson, R. R., Huffman, G. J., Luke, W. T., Nunnermacker, L. J., Pickering, K. E., Leslie, A. C. D., Lindsey, C. G., Slinn, W. G. N., Kelly, T. J., Daum, P. H., Delany, A. C., Greenberg, J. P., Zimmerman, P. R., Boatman, J. F., Ray, J. D., and Stedman, D. H.: Thunderstorms: An important mechanism in the transport of air pollutants, Science, 235, 460-464, https://doi.org/10.1126/science.235.4787.460, 1987.
Dickerson, R. R., Doddridge, B., Kelley, P., and Rhoads, K.: Large scale pollution of the atmosphere over the remote Atlantic Ocean: Evidence from Bermuda, J. Geophys. Res., 100, 89458952, https://doi.org/10.1029/95JD00073, 1995.

Dzepina, K., Mazzoleni, C., Fialho, P., China, S., Zhang, B., Owen, R. C., Helmig, D., Hueber, J., Kumar, S., Perlinger, J. A., Kramer, L. J., Dziobak, M. P., Ampadu, M. T., Olsen, S., Wuebbles, D. J., and Mazzoleni, L. R.: Molecular characterization of free tropospheric aerosol collected at the Pico Mountain Observatory: a case study with a long-range transported biomass burning plume, Atmos. Chem. Phys., 15, 5047-5068, https://doi.org/10.5194/acp-15-5047-2015, 2015.

Eckhardt, S., Stohl, A., Wernli, H., James, P., Forster, C., and Spichtinger, N.: A 15-year climatology of warm conveyor belts, J. Climate, 17, 218-237, https://doi.org/10.1175/15200442(2004)017<0218:AYCOWC>2.0.CO;2, 2004.

Fioletov, V. E., McLinden, C. A., Krotkov, N. A., Moran, M. D., and Yang, K.: Estimation of $\mathrm{SO}_{2}$ emissions using OMI retrievals, Geophys. Res. Lett., 38, L21811, https://doi.org/10.1029/2011GL049402, 2011.

Fioletov, V. E., McLinden, C. A., Krotkov, N., Li, C., Joiner, J., Theys, N., Carn, S., and Moran, M. D.: A global catalogue of large $\mathrm{SO}_{2}$ sources and emissions derived from the Ozone Monitoring Instrument, Atmos. Chem. Phys., 16, 11497-11519, https://doi.org/10.5194/acp-16-11497-2016, 2016.

Ginoux, P., Prospero, J. M., Gill, T. E., Hsu, N. C., and Zhao, M.: Global-scale attribution of anthropogenic and natural dust sources and their emission rates based on MODIS Deep Blue aerosol products, Rev. Geophys., 50, RG3005, https://doi.org/10.1029/2012RG000388, 2012.

Goldstein, A. H., Koven, C. D., Heald, C. L., and Fung, I. Y.: Biogenic carbon and anthropogenic pollutants combine to form a cooling haze over the southeastern United States, P. Natl. Acad. Sci. USA, 106, 8835-8840, https://doi.org/10.1073/pnas.0904128106, 2009.

Gravenhorst, G.: Maritime sulfate over the North Atlantic, Atmos. Environ., 12, 707-713, https://doi.org/10.1016/00046981(78)90251-2, 1978.

Guenther, A. B., Jiang, X., Heald, C. L., Sakulyanontvittaya, T., Duhl, T., Emmons, L. K., and Wang, X.: The Model of Emissions of Gases and Aerosols from Nature version 2.1 (MEGAN2.1): an extended and updated framework for modeling biogenic emissions, Geosci. Model Dev., 5, 1471-1492, https://doi.org/10.5194/gmd-5-1471-2012, 2012.

Honrath, R. E., Owen, R. C., Val Martin, M., Reid, J. S., Lapina, K., Fialho, P., Dziobak, M. P., Kleissl, J., and Westphal, D. L.: Regional and hemispheric impacts of anthropogenic and biomass burning emissions on summertime $\mathrm{CO}$ and $\mathrm{O}_{3}$ in the North Atlantic lower free troposphere, J. Geophys. Res.-Atmos., 109, D24310, https://doi.org/10.1029/2004JD005147, 2004.

IPCC, 2013: Climate change 2013, The physical science basis, Contribution of Working Group I to the Fifth Assessment Report of the Intergovernmental Panel on Climate, edited by: Stocker, T. F., Qin, D., Plattner, G. K. Tignor, M., Allen, S. K., Boschung, J., Nauels, A., Xia, Y., Bex V., and Midgley P. M., Cambridge University Press, Cambridge, UK and New York, NY, USA, 1535 pp., 2013.

Kalnay, E., Kanamitsu, M., Kistler, R., Collins, W., Deaven, D., Gandin, L., Iredell, M., Saha, S., White, G., Woollen, 
J., Zhu, Y., Leetmaa, A., Reynolds, R., Chelliah, M., Ebisuzaki, W., Higgins, W., Janowiak, J., Mo, K. C., Ropelewski, C., Wang, J., Jenne, R., and Joseph, D.: The NCEP/NCAR 40-Year Reanalysis Project, B. Am. Meteorol. Soc., 77, 437-471, https://doi.org/10.1175/15200477(1996)077<0437:TNYRP>2.0.CO;2, 1996.

Kim, P. S., Jacob, D. J., Fisher, J. A., Travis, K., Yu, K., Zhu, L., Yantosca, R. M., Sulprizio, M. P., Jimenez, J. L., CampuzanoJost, P., Froyd, K. D., Liao, J., Hair, J. W., Fenn, M. A., Butler, C. F., Wagner, N. L., Gordon, T. D., Welti, A., Wennberg, P. O., Crounse, J. D., St. Clair, J. M., Teng, A. P., Millet, D. B., Schwarz, J. P., Markovic, M. Z., and Perring, A. E.: Sources, seasonality, and trends of southeast US aerosol: an integrated analysis of surface, aircraft, and satellite observations with the GEOS-Chem chemical transport model, Atmos. Chem. Phys., 15, 10411-10433, https://doi.org/10.5194/acp-15-104112015, 2015.

Lawler, J. J., Lewis, D. J., Nelson, E., Plantinga, A. J., Polasky, S., Withey, J. C., Helmers, D. P., Martinuzzi, S., Pennington, D., and Radeloff, V. C.: Projected land-use change impacts on ecosystem services in the United States, P. Natl. Acad. Sci. USA, 111, 74927497, https://doi.org/10.1073/pnas.1405557111, 2014.

Li, Q., Jacob, D. J., Munger, J. W., Yantosca, R. M., and Parrish, D. D.: Export of NOy from the North American boundary layer: Reconciling aircraft observations and global model budgets, J. Geophys. Res., 109, D02313, https://doi.org/10.1029/2003jd004086, 2004.

Li, Q., Jacob, D., Park, R., Wang, Y., Heald, C., Hudman, R., Yantosca, R., Martin, R., and Evans, M.: North American pollution outflow and the trapping of convectively lifted pollution by upper-level anticyclone, J. Geophys. Res., 110, D10301, https://doi.org/10.1029/2004JD005039, 2005.

Mann, G. W., Carslaw, K. S., Spracklen, D. V., Ridley, D. A., Manktelow, P. T., Chipperfield, M. P., Pickering, S. J., and Johnson, C. E.: Description and evaluation of GLOMAP-mode: a modal global aerosol microphysics model for the UKCA composition-climate model, Geosci. Model Dev., 3, 519-551, https://doi.org/10.5194/gmd-3-519-2010, 2010.

Martinuzzi, S., Radeloff, V. C., Joppa, L. N., Hamilton, C. M., Helmers, D. P., Plantinga, A. J., and Lewis, D. J.: Scenarios of future land use change around United States' protected areas, Biol. Conserv., 184, 446-455, https://doi.org/10.1016/j.biocon.2015.02.015, 2015.

Merrill, J. T. and Moody, J. L.: Synoptic meteorology and transport during the North Atlantic Regional Experiment (NARE) intensive: Overview, J. Geophys. Res., 101, 28903-28921, https://doi.org/10.1029/96JD00097, 1996.

Millet, D. B., Jacob, D. J., Boersma, K. F., Fu, T. M., Kurosu, T. P., Chance, K., Heald, C. L., and Guenther, A.: Spatial distribution of isoprene emissions from North America derived from formaldehyde column measurements by the OMI satellite sensor, J. Geophys. Res., 113, D02307, https://doi.org/10.1029/2007JD008950, 2008.

MNP: Integrated modelling of global environmental change, an overview of IMAGE 2.4., edited by: Bouwman, A. F., Kram, T., and Klein Goldewijk, K., Netherlands Environmental Assessment Agency (MNP), Bilthoven, the Netherlands, 2006.

Moody, J. L., Davenport, J. C., Merrill, J. T., Oltmans, S. J., Parrish, D. D., Holloway, J. S., Levy II, H., Forbes, G. L., Trainer,
M., and Buhr M.: Meteorological mechanisms for transporting $\mathrm{O}_{3}$ over the western North Atlantic Ocean: A case study for 24-29 August 1993, J. Geophys. Res., 101, 29213-29277, https://doi.org/10.1029/96JD00885, 1996.

Myhre, G., Shindell, D., Bréon, F.-M., Collins, W., Fuglestvedt, J., Huang, J., Koch, D., Lamarque, J.-F., Lee, D., Mendoza, B., Nakajima, T., Robock, A., Stephens, G., Takemura, T., and Zhang, H.: Anthropogenic and Natural Radiative Forcing, in: Climate Change 2013: The Physical Science Basis, Contribution of Working Group I to the Fifth Assessment Report of the Intergovernmental Panel on Climate Change, edited by: Stocker, T. F., Qin, D., Plattner, G. K., Tignor, M., Allen, S. K., Boschung, J., Nauels, A., Xia, Y., Bex, V., and Midgley, P. M., Cambridge University Press, Cambridge, United Kingdom and New York, NY, USA, 2013.

Nordstrom, K. and Hotta, S.: Wind erosion from cropland solutions in the USA: a review of problems, and prospects, Geoderma, 121, 157-167, https://doi.org/10.1016/j.geoderma.2003.11.012, 2004.

Novlan, D. J., Hardiman, M., and Gill, T. E.: A synoptic climatology of blowing dust events in El Paso, Texas from 1932-2005, in: 16th Conference on Applied Climatology, American Meteorological Society Annual Meeting, 18 January 2007, San Antonio, TX, paper J3.12, 13 pp., available at: https://ams.confex. com/ams/87ANNUAL/techprogram/paper_115842.htm, 2007.

Owen, R. C., Cooper, O. R., Stohl, A., and Honrath, R. E.: An analysis of the mechanisms of North American pollutant transport to the central North Atlantic lower free troposphere, J. Geophys. Res., 111, D23S58, https://doi.org/10.1029/2006JD007062, 2006.

Park, R. J., Jacob, D. J., Chin, M., and Martin, R. V.: Sources of carbonaceous aerosols over the United States and implications for natural visibility, J. Geophys. Res., 108, 4355, https://doi.org/10.1029/2002JD003190, 2003.

Park, R. J., Jacob, D., Field, B. D., Yantosca, R., and Chin, M.: Natural and transboundary pollution influences on sulfate-nitrate-ammonium aerosols in the United States: Implications for policy, J. Geophys. Res., 109, D15204, https://doi.org/10.1029/2003JD004473, 2004

Park, S. S., Harrison, D., Pancras, J. P., and Ondov, J. M.: Highly time-resolved organic and elemental carbon measurements at the Baltimore Supersite in 2002, J. Geophys. Res.-Atmos., 110, D07S06, https://doi.org/10.1029/2004jd004610, 2005.

Parrish, D. D., Holloway, J. S., Trainer, M., Murphy, P. C., Forbers, G. L., and Fehsenfeld, F. C.: Relationships between ozone and carbon monoxide at surface sites in the North Atlantic region, J. Geophys. Res., 103, 13357-13376, https://doi.org/10.1029/98JD00376, 1998.

Pérez, C., Nickovic, S., Baldasano, J. M., Sicard, M., Rocadenbosch, F., and Cachorro, V. E.: A long Saharan dust event over the western Mediterranean: Lidar, Sun photometer observations, and regional dust modeling, J. Geophys. Res., 111, D15214, https://doi.org/10.1029/2005JD006579, 2006.

Pérez García-Pando, C., Miller, R. L., Perlwitz, J. P., Rodríguez, S., and Prospero, J. M.: Predicting the mineral composition of dust aerosols: Insights from elemental composition measured at the Izaña Observatory, Geophys. Res. Lett., 43, 10520-10529, https://doi.org/10.1002/2016GL069873, 2016. 
Prospero, J. M. and Carlson, T. N.: Vertical and areal distribution of Saharan dust over the western Equatorial North Atlantic Ocean, J. Geophys. Res., 77, 5255-5265, https://doi.org/10.1029/JC077i027p05255, 1972.

Querol, X., Alastuey, A., Viana, M. M., Rodríguez, S., Artiñano, B., Salvador, P., Santos, S. G. D., Patier, R. F., Ruiz, C. R., Rosa, J. D. L., Campa, A. S. D. L., Menedez, M., and Gil, J. I.: Speciation and origin of $\mathrm{PM}_{1} 0$ and $\mathrm{PM}_{2} .5$ in Spain, J. Aerosol Sci., 35, 1151-1172, https://doi.org/10.1016/j.jaerosci.2004.04.002, 2004.

Ramanathan, V., Crutzen, P. J., Kiehl, J. T., and Rosenfeld, D.: Aerosols, climate and the hydrological cycle, Science, 294, 2119-2124, https://doi.org/10.1126/science.1064034, 2001.

Randerson, J. T., van der Werf, G. R., Giglio, L., Collatz, G. J., and Kasibhatla, P. S.: Global Fire Emissions Database, Version 4, (GFEDv4), ORNL DAAC, Oak Ridge, Tennessee, USA, available at: http://dx.doi.org/10.3334/ORNLDAAC/1293 (last access: 14 December 2016), 2015.

Ripoll, A., Minguillón, M. C., Pey, J., Jimenez, J. L., Day, D. A., Sosedova, Y., Canonaco, F., Prévôt, A. S. H., Querol, $\mathrm{X}$., and Alastuey, A.: Long-term real-time chemical characterization of submicron aerosols at Montsec (southern Pyrenees, $1570 \mathrm{~m}$ a.s.1.), Atmos. Chem. Phys., 15, 2935-2951, https://doi.org/10.5194/acp-15-2935-2015, 2015.

Rodríguez, S., González, Y., Cuevas, E., Ramos, R., Romero, P. M., Abreu-Afonso, J., and Redondas, A.: Atmospheric nanoparticle observations in the low free troposphere during upward orographic flows at Izaña Mountain Observatory, Atmos. Chem. Phys., 9, 6319-6335, https://doi.org/10.5194/acp-9-6319-2009, 2009.

Rodríguez, S., Alastuey, A., Alonso-Pérez, S., Querol, X., Cuevas, E., Abreu-Afonso, J., Viana, M., Pérez, N., Pandolfi, M., and de la Rosa, J.: Transport of desert dust mixed with North African industrial pollutants in the subtropical Saharan Air Layer, Atmos. Chem. Phys., 11, 6663-6685, https://doi.org/10.5194/acp11-6663-2011, 2011.

Rodríguez, S., Cuevas, E., Prospero, J. M., Alastuey, A., Querol, X., López-Solano, J., García, M. I., and Alonso-Pérez, S.: Modulation of Saharan dust export by the North African dipole, Atmos. Chem. Phys., 15, 7471-7486, https://doi.org/10.5194/acp15-7471-2015, 2015.

Schaap, M., Spindler, G., Schulz, M., Acker, K., Maenhaut, W., Berner, A., Wieprecht, W., Streit, N., Müller, K., Brüggemann, E., Putaud, J.-P., Puxbaum, H., Baltensperger, U., and ten Brink, H. M.: Artefacts in the sampling of nitrate studied in the "INTERCOMP" campaigns of EUROTRAC-AEROSOL, Atmos. Environ., 38 , 6487-6496, https://doi.org/10.1016/j.atmosenv.2004.08.026, 2004.

Sindelarova, K., Granier, C., Bouarar, I., Guenther, A., Tilmes, S., Stavrakou, T., Müller, J.-F., Kuhn, U., Stefani, P., and Knorr, W.: Global data set of biogenic VOC emissions calculated by the MEGAN model over the last 30 years, Atmos. Chem. Phys., 14, 9317-9341, https://doi.org/10.5194/acp-14-9317-2014, 2014.

Squizzato, S., Masiol, M., Brunelli, A., Pistollato, S., Tarabotti, E., Rampazzo, G., and Pavoni, B.: Factors determining the formation of secondary inorganic aerosol: a case study in the Po Valley (Italy), Atmos. Chem. Phys., 13, 1927-1939, https://doi.org/10.5194/acp-13-1927-2013, 2013.
Stohl, A. and Seibert, P.: Accuracy of trajectories as determined from the conservation of meteorological tracers, Q. J. Roy. Meteor. Soc., 125, 1465-1484, https://doi.org/10.1002/qj.49712454907, 1998.

Stohl, A., Wotawa, G., Seibert, P., and Kromp-Kolb, H.: Interpolation errors in wind fields as a function of spatial and temporal resolution and their impact on different types of kinematic trajectories, J. Appl. Meteor., $\quad 34, \quad 2149-2165, \quad$ https://doi.org/10.1175/15200450(1995)034<2149:IEIWFA>2.0.CO;2, 1995.

Stohl, A.: A one-year Lagrangian "climatology" of airstreams in the North- ern Hemisphere troposphere and lowermost stratosphere, J. Geophys. Res., 106, 7263-7279, https://doi.org/10.1029/2000JD900570, 2001.

Stohl, A.: On the pathways and timescales of intercontinental air pollution transport, J. Geophys. Res., 107, 4684, https://doi.org/10.1029/2001JD001396, 2002.

Talbot, R. W., Dibb, J. E., and Loomis, M. B.: Influence of vertical transport on free tropospheric aerosols over the central USA in springtime, Geophys. Res. Lett., 25, 1367-1370, https://doi.org/10.1029/98GL00184, 1998.

US EPA: National air pollutant emissions trends, 1900-1998, EPA454/R-00-002, Off. of Air Qual. Planning and Stand., Research Triangle Park, N. C., 2000.

Val Martín, M., Honrath, R. E., Owen, R. C., Pfister, G., Fialho, P., and Barata, F.: Significant enhancements of nitrogen oxides, black carbon, and ozone in the North Atlantic lower free troposphere resulting from North American boreal wildfires, J. Geophys. Res., 111, D23S60, https://doi.org/10.1029/2006JD007530, 2006.

Vecchi, R., Valli, G., Fermo, P., D’Alessandro, A., Piazzalunga, A., and Bernardoni, V.: Organic and inorganic sampling artefacts assessment, Atmos. Environ., 43, 1713-1720, https://doi.org/10.1016/j.atmosenv.2008.12.016, 2009.

Whittaker, K. M. and Horn, L. H.: Northern hemisphere extra- tropical cyclone activity for four mid-season months, J. Climatol., 4, 297-310, https://doi.org/10.1002/joc.3370040307, 1984.

WHO: World Health Organization, 2014, Burden of disease from ambient and household air pollution, available at: http://www. who.int/phe/health_topics/outdoorair/databases/en/, last access: 23 February 2016

Wu, J. and Cho, S. H.: The effect of local land use regulations on urban development in the Western United States, Reg. Sci. Urban Econ., 37, 69-86, https://doi.org/10.1016/j.regsciurbeco.2006.06.008, 2007.

Wu, S., Mickley, L. J., Kaplan, J. O., and Jacob, D. J.: Impacts of changes in land use and land cover on atmospheric chemistry and air quality over the 21 st century, Atmos. Chem. Phys., 12, 15971609, https://doi.org/10.5194/acp-12-1597-2012, 2012.

Ying, Q., Li, J., and Kota, S. H.: Significant Contributions of Isoprene to Summertime Secondary Organic Aerosol in Eastern United States, Environ. Sci. Technol., 49, 7834-7842, https://doi.org/10.1021/acs.est.5b02514, 2015.

Zishka, K. M. and Smith, P. J.: The climatology of cyclones and anticyclones over North America and surrounding ocean environs for January and July, 1950-1977, Mon. Weather Rev., 108, 387-401, https://doi.org/10.1175/15200493(1980)108<0387:TCOCAA>2.0.CO;2, 1980. 